\title{
Physically Effective Fiber: Method of Determination and Effects on Chewing, Ruminal Acidosis, and Digestion by Dairy Cows
}

\author{
W. Z. Yang and K. A. Beauchemin ${ }^{1}$ \\ Agriculture and Agri-Food Canada, Research Centre, Lethbridge, AB, T1J 4B1, Canada
}

\begin{abstract}
A study was conducted to investigate the effects of physically effective neutral detergent fiber (peNDF) content of dairy cow diets containing corn silage as the sole forage on intake, chewing, ruminal $\mathrm{pH}$, microbial protein synthesis, digestibility, and milk production. A second objective was to compare current methods of measuring peNDF to determine the most suitable approach for use in ration formulation. The experiment was designed as a replicated $3 \times 3$ Latin square using 6 lactating dairy cows with ruminal cannulas. Diets varied in peNDF content (high, medium, and low) by altering the particle length of corn silage. The physical effectiveness factors (pef) and peNDF contents of the corn silage and diets were determined based on the original (19- and 8-mm sieves) and new Penn State Particle Separator (PSPS; 19-, 8-, and 1.18-mm sieves). A dry-sieving technique that measures the proportion of particles retained on a $1.18-\mathrm{mm}$ sieve was also used. The new PSPS and the 1.18-mm sieve produced similar estimates of pef and peNDF of diets but gave higher values than the original PSPS. There was a much smaller range in pef of corn silage when 3 sieves, rather than 2, were used with the PSPS (range of 0.93 to 0.96 vs. 0.41 to 0.72 , respectively). Consequently, increased forage particle length in the diets increased dietary peNDF content and its intake when using the original PSPS; however, the new PSPS and the 1.18-mm sieve failed to detect changes in dietary peNDF and peNDF intake. The peNDF values estimated based on fractional NDF rather than the total NDF content were higher, but the ranking of diets was not changed. Increased intake of peNDF linearly increased digestibility of $\mathrm{CP}$ and tended to linearly increase digestibility of fiber in the total tract. As a result, milk yield tended to linearly increase with no effect on milk composition. Ruminal microbial protein synthesis and microbial efficiency were higher with the medium peNDF than with the high or low peNDF diets. Total chewing time and
\end{abstract}

Received November 10, 2005.

Accepted February 2, 2006.

${ }^{1}$ Corresponding author: beauchemink@agr.gc.ca ruminating time were linearly increased with increasing dietary peNDF, whereas influence of dietary peNDF on ruminal $\mathrm{pH}$ and fermentation was minimal. This study showed that increasing peNDF content of diets improved fiber digestion. Of the systems used to measure peNDF, the original PSPS provided a good description of dietary particle length and its effects on chewing time and rumen $\mathrm{pH}$, whereas the new PSPS provided a more consistent chewing index, the ratio of total chewing activity to peNDF, across diets varying in chop length of corn silage.

Key words: physically effective neutral detergent fiber, chewing, digestion, dairy cow

\section{INTRODUCTION}

Providing sufficient physically effective fiber (peNDF) in diets fed to high-producing dairy cows is necessary to prevent subclinical ruminal acidosis and the resulting depressions in milk fat, DMI, and fiber digestion, and increase in lameness (NRC, 2001). The concept of peNDF incorporates information on dietary particle length and the chemical NDF content of the diet in a manner that predicts the physical effectiveness of the diet (Mertens, 1997). However, the most appropriate means of measuring peNDF content of the forage or diet is uncertain. A laboratory method was proposed by Mertens (1997) that determines peNDF as the proportion of DM retained on a 1.18-mm sieve multiplied by dietary NDF content (peNDF $\mathbf{1 . 1 8}_{\mathbf{1}}$ ). Lammers et al. (1996) developed a practical device, known as the Penn State Particle Separator (PSPS), for routine on-farm use to measure the peNDF of forages and TMR. The proportion of DM retained by the 19- and 8-mm sieves of the PSPS multiplied by dietary NDF is $\mathbf{p e N D F}_{\mathbf{p s}-2 \mathbf{s}}$. Kononoff et al. (2003a) added an additional 1.18-mm sieve to the PSPS, so that it determines peNDF as a proportion of DM retained by 19-, 8-, and 1.18-mm sieves of the PSPS multiplied by dietary NDF $\left(\mathbf{p e N D F}_{\mathbf{p s - 3 s}}\right)$. The additional sieve was added to be consistent with the system developed by Mertens (1997) and because $1.18 \mathrm{~mm}$ is considered to be a critical length governing retention of particles in the reticulorumen (Poppi and Norton, 1980). Because NDF content varies 
among PSPS fractions, peNDF is sometimes determined as the amount of NDF retained by the PSPS, multiplied by the respective DM percentage of the individual sieves (Einarson et al., 2004).

It is unclear which measure of peNDF and what peNDF contents provide the most accurate estimation of chewing activity and ruminal $\mathrm{pH}$ in dairy cows, although a number of studies have been conducted in recent years (Yang et al., 2001; Krause et al., 2002b; Beauchemin et al., 2003; Kononoff et al., 2003b; Yansari et al., 2004; Beauchemin and Yang, 2005). These different methods of peNDF estimation result in very different values (Yang et al., 2001; Beauchemin et al., 2003; Einarson et al., 2004). Yansari et al. (2004) showed that chewing activity per unit intake of peNDF was consistent across diets varying in particle length when estimated using systems that incorporated a $1.18-\mathrm{mm}$ sieve (i.e., peNDF ${ }_{1.18}$ or peNDF $\mathrm{Ns}_{\mathrm{ps}-3 \mathrm{~s}}$ ). A consistent ratio of chewing activity to peNDF is desirable in terms of predicting chewing time based on peNDF intake. However, in some studies, peNDF $_{\mathrm{ps}-3 \mathrm{~s}}$ did not differentiate diets that differed in forage particle length (Kononoff and Heinrichs, 2003b).

Increased chewing activity as a result of increased peNDF intake can increase ruminal $\mathrm{pH}$, and help minimize ruminal acidosis in dairy cows (Krause et al., 2002b; Yansari et al., 2004). However, this is not always the case; chewing activity can also increase with increasing intake of peNDF without affecting ruminal $\mathrm{pH}$, particularly when diets contain highly fermentable carbohydrate sources (Kononoff et al., 2003b; Kononoff and Heinrichs, 2003a; Beauchemin and Yang, 2005). Thus, it is not clear whether systems of measuring peNDF are useful for predicting both chewing and ruminal $\mathrm{pH}$.

A number of studies on the effects of peNDF on feed intake, digestibility, and milk production and composition have also been conducted (Krause et al., 2002a; Kononoff et al., 2003a; Plaizier, 2004; Yansari et al., 2004; Yang and Beauchemin, 2005). However, the results have been inconclusive due to differences in measuring peNDF.

The objectives of the present study were to determine the effect of increasing the peNDF content of a diet containing CS on feed intake, chewing activity, ruminal $\mathrm{pH}$ and fermentation, microbial protein synthesis, digestibility, and milk production in lactating dairy cows. The second objective was to determine the most appropriate method of determining peNDF for use in diet formulation to promote chewing and prevent ruminal acidosis. Thus, the peNDF content of the diets was determined using the PSPS with 2 and 3 sieves, and by expressing the values as a proportion of DM and NDF, and using a dry sieving technique as particles retained on a 1.18-mm sieve (Mertens, 1997).

\section{MATERIALS AND METHODS}

\section{Corn Silage}

Whole plant corn (hybrid 39T68, Pioneer Hi-Bred International, Des Moines, IA) was harvested at a moisture content of $60 \%$ from a single field using a selfpropelled forage harvester (model FX58, New Holland, PA) set to obtain a theoretical cut length (TCL) of 28.6, 15.9 , and $4.8 \mathrm{~mm}$ for long, medium, and short, respectively, with kernel processing at a $2-\mathrm{mm}$ roll clearance. The chopped forages were ensiled on the same day in large silo bags (200-tonne capacity) for 2 mo before being used. Fermentation characteristics of the silage as sampled from the silo before starting the experiment are presented in Table 1 . These analyses were conducted commercially by Cumberland Valley Analytical Service, Inc. (Maugansville, MD).

\section{Cows and Diets}

Six multiparous lactating Holstein cows fitted with ruminal cannulas, averaging $664 \pm 62 \mathrm{~kg}$ of $\mathrm{BW}$ and $120 \pm 63$ DIM, were assigned randomly to two $3 \times 3$ Latin squares balanced for carryover effects. The 2 squares were conducted simultaneously. Cows were housed in individual tie stalls and offered a TMR 3 times daily at 0600,1500 , and $1800 \mathrm{~h}$ for ad libitum intake. Cows were cared for according to the Canadian Council on Animal Care Guidelines (Ottawa, ON, Canada).

Cows were offered 1 of 3 diets, which were chemically identical with approximately $54 \%$ of concentrate and $46 \%$ of corn silage (CS; Table 2), but differed in peNDF level: high, medium, and low. The 3 dietary peNDF levels were obtained using CS differing in particle length: long silage (high), medium silage (medium), and short silage (low) (Table 3). The diets were formulated using the Cornell-Penn-Miner System (CPMDairy, Version 3.0.4a; Cornell University, Ithaca, NY; University of Pennsylvania, Kennett Square, PA; and William H. Miner Agricultural Research Institute, Chazy, NY) to supply adequate ME and MP for a 650-kg cow producing $35 \mathrm{~kg} / \mathrm{d}$ of milk containing $3.5 \%$ fat and $3.2 \%$ protein. Each period consisted of $11 \mathrm{~d}$ for adaptation to diets and $10 \mathrm{~d}$ for experimental measurements.

Feed offered and orts were measured for each cow and recorded daily during the last $10 \mathrm{~d}$ of the period to calculate feed intake. Samples of CS and each TMR were collected once weekly, and orts were collected daily and composited weekly by cow for particle distribution 
YANG AND BEAUCHEMIN

Table 1. Chemical composition and fermentation parameters of corn silage

\begin{tabular}{|c|c|c|c|c|c|c|}
\hline \multirow[b]{2}{*}{ Item } & \multicolumn{3}{|c|}{ Corn silages } & \multirow[b]{2}{*}{ SE } & \multicolumn{2}{|c|}{ Effects } \\
\hline & Long & Medium & Short & & Linear & Quadratic \\
\hline \multicolumn{7}{|l|}{ Chemical composition } \\
\hline $\mathrm{DM}, \%$ & 45.3 & 47.8 & 44.2 & 1.2 & NS & 0.04 \\
\hline $\mathrm{OM}, \%$ of $\mathrm{DM}$ & 95.8 & 95.8 & 95.3 & 0.3 & NS & NS \\
\hline $\mathrm{NDF}, \%$ of DM & 49.3 & 46.3 & 47.8 & 1.5 & NS & 0.08 \\
\hline $\mathrm{ADF}, \%$ of $\mathrm{DM}$ & 25.9 & 23.2 & 27.4 & 1.2 & 0.12 & 0.05 \\
\hline Starch, \% of DM & 28.0 & 28.6 & 27.1 & 1.5 & NS & NS \\
\hline $\mathrm{CP}, \%$ of $\mathrm{DM}$ & 9.7 & 9.6 & 9.8 & 0.1 & NS & NS \\
\hline \multicolumn{7}{|l|}{ Fermentation $^{1}$} \\
\hline $\mathrm{pH}$ & 4.09 & 4.13 & 4.10 & - & - & - \\
\hline Lactic acid, \% of DM & 3.3 & 3.3 & 3.8 & - & - & - \\
\hline Acetic acid, \% of DM & 1.04 & 0.75 & 1.66 & - & - & - \\
\hline Propionic acid, \% of DM & $<0.01$ & $<0.01$ & $<0.01$ & - & - & - \\
\hline Ammonia, \% of DM & 0.7 & 0.2 & 0.5 & - & - & - \\
\hline
\end{tabular}

${ }^{1}$ Fermentation parameters were determined by Cumberland Valley Analytical Service, Inc. (Maugansville, MD) with a single representative sample.

$\mathrm{NS}=P>0.15$.

Table 2. Ingredients and chemical composition of the total mixed $\operatorname{diet}^{1}$ (DM basis)

\begin{tabular}{|c|c|c|c|c|c|c|}
\hline \multirow[b]{2}{*}{ Item } & \multicolumn{3}{|c|}{ Diet } & \multirow[b]{2}{*}{ SE } & \multicolumn{2}{|c|}{ Effects } \\
\hline & Long & Medium & Short & & Linear & Quadratic \\
\hline \multicolumn{7}{|l|}{ Ingredients, \% } \\
\hline Corn silage, long cut & 45.8 & - & - & - & - & - \\
\hline Corn silage, medium cut & - & 45.8 & - & - & - & - \\
\hline Corn silage, short cut & - & - & 45.8 & - & - & - \\
\hline Corn grain, dry-rolled ${ }^{2}$ & 34.3 & 34.3 & 34.3 & - & - & - \\
\hline Corn gluten meal & 1.83 & 1.83 & 1.83 & - & - & - \\
\hline Heat-treated canola meal (Alberta Gold) ${ }^{3}$ & 1.83 & 1.83 & 1.83 & - & - & - \\
\hline Soybean meal & 11.45 & 11.45 & 11.45 & - & - & - \\
\hline Beet molasses & 0.46 & 0.46 & 0.46 & - & - & - \\
\hline Urea & 0.46 & 0.46 & 0.46 & - & - & - \\
\hline Calcium carbonate & 1.28 & 1.28 & 1.28 & - & - & - \\
\hline Dicalcium phosphorus & 0.64 & 0.64 & 0.64 & - & - & - \\
\hline Vitamin-mineral mix $^{4}$ & 1.01 & 1.01 & 1.01 & - & - & - \\
\hline Canola oil & 0.69 & 0.69 & 0.69 & - & - & - \\
\hline Binding agent & 0.18 & 0.18 & 0.18 & - & - & - \\
\hline Flavoring agent & 0.01 & 0.01 & 0.01 & - & - & - \\
\hline $\mathrm{YbCl}_{3}(34.5 \% \mathrm{wt} / \mathrm{wt})$, digestive marker & 0.04 & 0.04 & 0.04 & - & - & - \\
\hline \multicolumn{7}{|l|}{ Chemical composition } \\
\hline DM, \% & 62.6 & 63.6 & 61.7 & 0.6 & NS & 0.08 \\
\hline $\mathrm{OM}, \%$ of $\mathrm{DM}$ & 93.1 & 93.1 & 93.2 & 0.3 & NS & NS \\
\hline $\mathrm{CP}, \%$ of $\mathrm{DM}$ & 16.8 & 16.5 & 16.5 & 0.2 & NS & NS \\
\hline $\mathrm{NDF}, \%$ of DM & 31.6 & 30.6 & 31.2 & 0.4 & NS & 0.02 \\
\hline NDF from forages, $\%$ of NDF & 71.4 & 69.3 & 70.2 & 2.2 & NS & NS \\
\hline $\mathrm{ADF}, \%$ of $\mathrm{DM}$ & 15.1 & 13.0 & 14.9 & 0.6 & NS & 0.05 \\
\hline Starch, \% of DM & 41.2 & 40.8 & 39.7 & 0.4 & 0.06 & NS \\
\hline
\end{tabular}

${ }^{1}$ Diet was formulated with CPMDairy 3.0.4a; peNDF = physically effective NDF.

${ }^{2}$ Chemical composition of corn grain (DM basis) was 95.3, 12.3, 2.7, and 9.7\% for OM, NDF, ADF, and $\mathrm{CP}$, respectively.

${ }^{3}$ Canbra Foods Ltd., Lethbridge, AB, Canada.

${ }^{4}$ Contained 58.8\% NaCl, $16.0 \%$ Dynamate (Pitman Moore, Inc., Mundelein, IL; $18 \% \mathrm{~K}, 11 \% \mathrm{Mg}, 22 \%$ $\mathrm{S}, 1000 \mathrm{mg} \mathrm{Fe} / \mathrm{kg}), 2 \% \mathrm{ZnSO}_{4} \cdot \mathrm{H}_{2} \mathrm{O}, 2.4 \% \mathrm{MnSO}_{4} \cdot 4 \mathrm{H}_{2} \mathrm{O}, 0.01 \% \mathrm{CoSO}_{4} \cdot 6 \mathrm{H}_{2} \mathrm{O}, 0.009 \% \mathrm{Na}_{2} \mathrm{SeO}_{3}, 0.012 \%$ ethylenediamine dihydroiodide, $0.8 \% \mathrm{CuSO}_{4} \cdot 5 \mathrm{H}_{2} \mathrm{O}, 2,000,000 \mathrm{IU} / \mathrm{kg}$ of vitamin $\mathrm{A}, 200,000 \mathrm{IU} / \mathrm{kg}$ of vitamin $\mathrm{D}$ and $2,000 \mathrm{IU} / \mathrm{kg}$ of vitamin $\mathrm{E}$.

$\mathrm{NS}=P>0.15$. 
Table 3. Particle size distribution, physical effectiveness factors (pef), and physically effective fiber (peNDF) contents of corn silage (CS)

\begin{tabular}{|c|c|c|c|c|c|c|}
\hline \multirow[b]{2}{*}{ Item } & \multicolumn{3}{|c|}{ Particle length } & \multirow[b]{2}{*}{$\mathrm{SE}$} & \multicolumn{2}{|c|}{ Effects } \\
\hline & Long & Medium & Short & & Linear & Quadratic \\
\hline \multicolumn{7}{|l|}{ PSPS $^{1}$} \\
\hline \multicolumn{7}{|l|}{$\%$ DM retained on sieves } \\
\hline $19 \mathrm{~mm}$ & 10.2 & 8.3 & 2.7 & 0.6 & 0.01 & 0.02 \\
\hline $8 \mathrm{~mm}$ & 61.3 & 59.8 & 38.7 & 0.6 & 0.01 & 0.01 \\
\hline $1.18 \mathrm{~mm}$ & 24.0 & 27.6 & 51.5 & 0.5 & 0.01 & 0.01 \\
\hline Pan & 4.5 & 4.3 & 7.2 & 0.3 & 0.01 & 0.01 \\
\hline pef $_{\mathrm{ps}-2 \mathrm{~s}}$ & 0.72 & 0.68 & 0.41 & 0.01 & 0.01 & 0.01 \\
\hline pef $f_{\mathrm{ps}-3 \mathrm{~s}}$ & 0.96 & 0.96 & 0.93 & 0.01 & 0.01 & 0.01 \\
\hline $\mathrm{peNDF}_{\mathrm{ps}-2 \mathrm{~s}}, \%$ of DM & 35.2 & 31.5 & 17.4 & 1.0 & 0.01 & 0.01 \\
\hline peNDF ${ }_{\text {ps-2sndf }} \%$ of DM & 38.2 & 34.6 & 19.8 & 0.7 & 0.01 & 0.01 \\
\hline peNDF ${ }_{\mathrm{ps}-3 \mathrm{~s}}, \%$ of DM & 47.0 & 44.3 & 44.4 & 1.5 & 0.07 & NS \\
\hline $\mathrm{peNDF}_{\mathrm{ps}-3 \mathrm{sndf}}, \%$ of DM & 50.1 & 48.2 & 47.3 & 0.6 & 0.03 & NS \\
\hline \multicolumn{7}{|l|}{ Dry sieving ${ }^{2}$. } \\
\hline \multicolumn{7}{|l|}{$\%$ DM retained on sieves } \\
\hline $9.5 \mathrm{~mm}$ & 15.6 & 15.4 & 6.2 & 4.2 & NS & NS \\
\hline $6.7 \mathrm{~mm}$ & 18.2 & 19.5 & 10.1 & 4.0 & 0.04 & 0.11 \\
\hline $3.35 \mathrm{~mm}$ & 35.3 & 31.1 & 35.4 & 2.0 & NS & 0.14 \\
\hline $1.18 \mathrm{~mm}$ & 22.3 & 24.1 & 29.7 & 3.4 & 0.12 & NS \\
\hline $0.6 \mathrm{~mm}$ & 4.6 & 5.5 & 10.4 & 1.1 & 0.01 & 0.04 \\
\hline $0.15 \mathrm{~mm}$ & 2.2 & 3.3 & 5.2 & 1.1 & 0.01 & NS \\
\hline$<0.15 \mathrm{~mm}$ & 1.9 & 1.0 & 3.0 & 0.9 & NS & 0.14 \\
\hline pef $_{1.18}$ & 0.91 & 0.90 & 0.82 & 0.02 & 0.01 & 0.06 \\
\hline peNDF $_{1.18}, \%$ of DM & 45.0 & 41.8 & 39.0 & 2.2 & 0.01 & NS \\
\hline
\end{tabular}

$\mathrm{NS}=P>0.15$.

${ }^{1}$ Particle size distribution of CS was measured using the Penn State Particle Separator (PSPS, Kononoff et al., 2003a); pef ${ }_{\mathrm{ps}-2 \mathrm{~s}}$ and pef $\mathrm{ps}_{\mathrm{ps}}=$ physical effectiveness factor determined as the proportion of particles retained on 2 sieves (Lammers et al., 1996) and on 3 sieves (Kononoff et al., 2003a), respectively; peNDF ps${ }_{2 \mathrm{~s}}$ and $\mathrm{peNDF}_{\mathrm{ps}-3 \mathrm{~s}}=$ physically effective NDF determined as NDF content of CS multiplied by pef $f_{\mathrm{ps}-2 \mathrm{~s}}$ and pef $_{\mathrm{ps}-3 \mathrm{~s}}$, respectively; peNDF $\mathrm{ps}_{\mathrm{2sndf}}$ and $\mathrm{peNDF}_{\mathrm{ps}-3 \mathrm{sndf}}=$ proportion of NDF retained on 2 sieves (Lammers et al., 1996) or on 3 sieves (Kononoff et al., 2003a), respectively.

${ }^{2}$ Particle size distribution of CS was measured by dry sieving using a vertical oscillating sieve shaker (Analysette 3; Fritsch, Oberstein, Germany) equipped with a stack of sieves (W. S. Tyler, Inc., Mentor, OH) arranged in descending mesh size; pef ${ }_{1.18}$ = physical effectiveness factor based on DM retained on a 1.18$\mathrm{mm}$ sieve (Mertens, 1997); peNDF $_{1.18}=$ physically effective NDF determined as NDF content of feed multiplied by pef $_{1.18}$.

analysis and DM determination, and then composited by period for each cow. The composited samples were dried in an oven at $55^{\circ} \mathrm{C}$ for $48 \mathrm{~h}$, ground through a 1mm diameter sieve (standard model 4, Arthur Thomas Co., Philadelphia, PA), and retained for chemical analysis.

\section{Meal Duration and Feeding Behavior}

Feeding behavior was monitored for $48 \mathrm{~h}$ on $\mathrm{d} 13$ to 15 of the period. Mangers attached to load cells (Omega Engineering Inc., Stamford, CT) that were connected to a computer were used to measure the feed weight over time. An average weight was obtained every 11 $\mathrm{s}$, and stored using Collect software (Labtronics, Inc., Guelph, ON, Canada). During feeding activity, the weight of the manger decreased. Feeding activity was separated into meals using a meal criterion of $27 \mathrm{~min}$ as outlined by DeVries et al. (2003). A meal criterion is the minimum time interval between 2 meals and is used to determine meal frequency and meal duration. A meal was defined as eating activity greater than 30 $\mathrm{s}$ and more than $300 \mathrm{~g}$ of feed being removed from the feeder. Rate of DMI was calculated as the ratio of DM ingested and duration of the meal.

\section{Chewing Activity}

Chewing activity was measured concurrently with feeding behavior. Cows were fitted for $48 \mathrm{~h}$ with leather halters that measured jaw movements. Each halter contained a piezo disk (Edmund Scientific Company, Barrington, NJ), which was inserted within the halter, and positioned under the jaw. Chewing action places stress on the disk generating an electrical signal, which is then processed and counted as a single jaw movement. A datalogger (Campbell Scientific, Inc., Logan, UT) was used to receive the output signal from each cow. The number of jaw movements was summed each minute and stored for subsequent analysis. The jaw movements 
were then designated as eating or ruminating chews based on several criteria. Jaw movements were considered as eating chews if they occurred during a meal (i.e., duration of the eating activity was greater than $30 \mathrm{~s}$ and more than $300 \mathrm{~g}$ of feed was removed from the feeder during the meal). Jaw movements were designated as ruminating chews if they did not occur during a meal and rate of chewing exceeded 30 chews $/ \mathrm{min}$. All other jaw movements were considered associated with licking, drinking, and grooming and were not included in the eating or ruminating categories. Total number of chews was calculated as the sum of eating and ruminating chews. Total time spent eating, ruminating, and chewing (eating + ruminating) was based on the duration of chewing activity.

\section{Ruminal $\mathrm{pH}$ and Fermentation}

Ruminal $\mathrm{pH}$ was monitored for $48 \mathrm{~h}$ concurrent with measurements of feeding behavior and chewing activity. The $\mathrm{pH}$ was measured using an industrial electrode (model S650-CDHF, Sensorex, Garden Grove, CA) linked to a pH controller (model PHCN-37, Omega Engineering Inc.) as described in detail by Penner et al. (2006). The electrodes were suspended approximately $60 \mathrm{~cm}$ in the rumen using a cable that was anchored to the ruminal cannula plug. The electrode was weighted down to ensure submersion within the rumen contents. This indwelling continuous ruminal $\mathrm{pH}$ measurement device results in values that are about 0.05 units lower than manual measurements of $\mathrm{pH}$ taken from the same location within the rumen (Penner et al., 2006). The electrodes were covered with a perforated guard to prevent them from coming into direct contact with the rumen wall. The $\mathrm{pH}$ electrodes were removed from the rumen for 20 min daily between 1400 and $1430 \mathrm{~h}$ for calibration using $\mathrm{pH} 4.0$ and 7.0 standards. Continuous measurements from the indwelling probe were sent to a datalogger (Campbell Scientific, Inc.) every $5 \mathrm{~s}$ and averaged every 5 min. Ruminal $\mathrm{pH}$ data were summarized daily for each cow as mean $\mathrm{pH}$, minimum $\mathrm{pH}$, area between the observed $\mathrm{pH}$ and a line drawn at $\mathrm{pH}$ 5.8 or 5.5 , and time (h) under $\mathrm{pH} 5.8$ or 5.5. The minimum $\mathrm{pH}$ value for each day and each cow was obtained from the raw input data using PROC MEANS (SAS Institute, 1996). The area was calculated by adding the absolute value of negative deviations in $\mathrm{pH}$ from 5.5 or 5.8 for each 5-min interval. A ruminal pH of 5.8 was chosen as benchmark because this threshold value is often used to indicate subclinical ruminal acidosis. The $\mathrm{pH}$ of 5.5 was used to further categorize subclinical ruminal acidosis in terms of severity.

Ruminal fluid was collected on d 13 at 0900, 1300, and $1600 \mathrm{~h}$ from multiple sites in the rumen for VFA and $\mathrm{NH}_{3} \mathrm{~N}$ determination. Samples were immediately squeezed through 4 layers of cheesecloth with a mesh size of $250 \mu \mathrm{m}$. Five milliliters of filtrate was preserved by adding $1 \mathrm{~mL}$ of $25 \% \mathrm{HPO}_{3}$ and used to determine VFA, and $5 \mathrm{~mL}$ of filtrate was preserved by adding 1 $\mathrm{mL}$ of $1 \% \mathrm{H}_{2} \mathrm{SO}_{4}$ and used to determine $\mathrm{NH}_{3} \mathrm{~N}$. The samples were subsequently stored frozen at $-20^{\circ} \mathrm{C}$ until analyzed.

\section{Apparent Digestion in the Total Tract}

Apparent total tract digestion of nutrients was measured using $\mathrm{YbCl}_{3}$ (Rhône-Poulenc Inc., Shelton, CT). Ytterbium product was mixed into the concentrate portion of the diets at a rate of $400 \mathrm{~g}$ of $\mathrm{YbCl}_{3} / \mathrm{t}$ of concentrate to achieve intake of approximately $1 \mathrm{~g}$ of $\mathrm{Yb} / \mathrm{d}$ per cow. Fecal samples (approximately $200 \mathrm{~g}$, wet weight) were collected for each cow from the rectum twice daily at various times during the last $6 \mathrm{~d}$ of the period. Samples were immediately subsampled (about $50 \mathrm{~g}$ ), composited across sampling times for each cow and each period, dried at $55^{\circ} \mathrm{C}$, ground to pass a $1-\mathrm{mm}$ sieve (standard model 4, Arthur Thomas Co.), and stored for chemical analysis. Apparent nutrient digestibility in the total tract was calculated from concentrations of $\mathrm{Yb}$ and nutrients in the diet, orts, and feces using the following equation: apparent digestibility $=100-[100$ $\left.\times\left(\mathrm{Yb}_{\mathrm{d}} / \mathrm{Yb}_{\mathrm{f}}\right) \times\left(\mathrm{N}_{\mathrm{f}} / \mathrm{N}_{\mathrm{d}}\right)\right]$, where $\mathrm{Yb}_{\mathrm{d}}=\mathrm{Yb}$ concentration in the diet actually consumed (i.e., after adjustment for $\mathrm{Yb}$ concentration of orts), $\mathrm{Yb}_{\mathrm{f}}=\mathrm{Yb}$ concentration in the feces, $N_{f}=$ concentration of the nutrient in the feces, and $\mathrm{N}_{\mathrm{d}}=$ concentration of the nutrient in the diet actually consumed.

\section{Microbial Protein Synthesis}

A mixed ruminal liquid and solid sample (about 0.8 L) from various locations of the rumen was obtained daily from each cow during the last $5 \mathrm{~d}$ of the period. Samples were squeezed immediately through 4 layers of cheesecloth. Ruminal particles obtained by squeezing were blended ( $400 \mathrm{~g}$ of particles plus $400 \mathrm{~mL}$ of $0.9 \%$ $\mathrm{NaCl}$ ) in a Waring blender (Waring Products Division, New Hartford, CT) for $1 \mathrm{~min}$, and then squeezed through 4 layers of cheesecloth. Filtrates from squeezed and strained homogenate were mixed, centrifuged (800 $\times g$ for $10 \mathrm{~min}$ at $4^{\circ} \mathrm{C}$ ) to remove protozoa and feed particles, and the supernatant was centrifuged $(27,000$ $\times g$ for 30 min at $4^{\circ} \mathrm{C}$ ) to obtain a mixed ruminal bacteria pellet. Bacterial isolates were accumulated by period for each cow, freeze-dried, and ground using a ball mill (Mixer Mill MM2000; Retsch, Haan, Germany) to a fine powder for chemical determination.

Total urine was collected from each cow on $\mathrm{d} 16$ to 18 using indwelling Foley catheters (26 French, 75-cc 
ballon; C. R. Bard, Inc., Covington, GA), which were inserted on d 16 of each experimental period. Fresh containers with $600 \mathrm{~mL}$ of $4 \mathrm{~N} \mathrm{H}_{2} \mathrm{SO}_{4}$ were attached to catheters at 1100 and $2300 \mathrm{~h}$ to obtain daily samples (final $\mathrm{pH}<3$ ). Urine output was measured every $12 \mathrm{~h}$ for $2 \mathrm{~d}$, and then 2 sets of $3-\mathrm{mL}$ aliquots were taken, diluted to $15 \mathrm{~mL}$ with distilled water, and stored at $-20^{\circ} \mathrm{C}$ for analysis of allantoin and uric acid.

Total purine derivatives $(\mathbf{P D})$ excreted $(\mathrm{mmol} / \mathrm{d})$ were estimated as the sum of uric acid and allantoin. Excretion of the endogenous PD was assumed constant at $0.385 \mathrm{mmol} / \mathrm{kg}$ of $\mathrm{BW}^{0.75}$ for individual cows (Chen and Gomes, 1992). Purine absorption of microbial origin was calculated as: (total PD excreted - endogenous PD)/ 0.85 (Chen and Gomes, 1992). Synthesis of microbial $\mathrm{N}$ within the rumen was calculated as: (purine absorption $\times 70$ )/(purine $\mathrm{N}$ :total $\mathrm{N}$ in mixed rumen bacteria $\times$ $0.83 \times 1,000)$ (Chen and Gomes, 1992). The average purine $\mathrm{N}$ :total $\mathrm{N}$ in mixed rumen bacteria measured in this study was 0.129 .

\section{Chemical Analyses}

Dry matter content of the ingredients (silage, grain, concentrate mix) and TMR was determined by oven drying at $55^{\circ} \mathrm{C}$ for $48 \mathrm{~h}$. Analytical DM content of ovendried samples was determined by drying at $135^{\circ} \mathrm{C}$ for $3 \mathrm{~h}$ (AOAC, 1990). The OM content was calculated as the difference between DM and ash contents, with ash determined by combustion at $550^{\circ} \mathrm{C}$ overnight. The $\mathrm{NDF}$ and ADF contents were determined using the methods described by Van Soest et al. (1991) with amylase and sodium sulfite used in the NDF procedure. Starch was determined by enzymatic hydrolysis of $\alpha$ linked glucose polymers as described by Rode et al. (1999). Content of $\mathrm{Yb}$ in the TMR, orts, and fecal samples was determined using inductively coupled plasma optical emission spectroscopy according to the AOAC method (1990) modified such that no $\mathrm{KCl}$ was used during sample digestion. Content of $\mathrm{N}$ in the samples was determined according to the method of Smith and Tabatabai (2004) by flash combustion, chromatographic separation, and thermal conductivity detection (Carlo Erba Instruments, Milan, Italy). Ruminal VFA were separated and quantified by gas chromatography (Varian 3700; Varian Specialties Ltd., Brockville, ON) using a $15-\mathrm{m}$ (0.53-mm i.d.) fused silica column (DB-FFAP column; J and W Scientific, Folsom, CA). Ammonia content of ruminal samples was determined using the method described by Weatherburn (1967) modified to use a plate reader. Allantoin in urine was determined by autoanalyzer using the procedure of Pentz (1969) with modifications by Lindberg and Jansson (1989). Uric acid was determined using a commercial kit (no.
292; Sigma Chemical Co., St. Louis, MO). Purine content in the bacterial pellet was determined using the procedure of Zinn and Owens (1986).

The pef of CS and TMR were determined using dry sieving techniques. Firstly, pef was determined using the PSPS as the proportion of DM retained on 2 sieves:

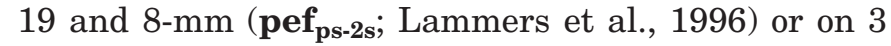
sieves: 19,8 , and 1.18-mm (pef ps-3s; $_{\text {; }}$ Kononoff et al., 2003a). The NDF content of the original sample and of all materials retained on the sieves was measured. The pef was also determined using a vertical oscillating sieve shaker (Analysette 3; Fritsch, Oberstein, Germany) equipped with a stack of sieves (W. S. Tyler, Inc., Mentor, $\mathrm{OH}$ ) arranged in descending mesh size. Sieve mesh sizes for the shaker were 9.5, 6.7, 3.35, 1.18, 0.6, and $0.15 \mathrm{~mm}$. Approximately $15 \mathrm{~g}$ of feed was placed on the top sieve, and the stack of sieves was shaken until the distribution of material did not change (approximately $10 \mathrm{~min}$ ). In this case, the pef was determined based on the proportion of DM retained on the 1.18-mm sieve (pef $\mathbf{f}_{\mathbf{1 . 1 8}}$ ), according to Mertens (1997).

The peNDF $\mathrm{ps}_{\mathrm{ps}}$, peNDF $\mathrm{ps}_{\mathrm{ps}}$, and peNDF ${ }_{1.18}$ were calculated by multiplying NDF content of the feed by the pef $_{\text {ps-2s, }}$ pef $f_{\text {ps-3s }}$, and pef $f_{1.18}$, respectively. The peNDF was also calculated (peNDF $\mathbf{p s - 2 s n d f}_{\text {and }}$ aeNDF $\mathbf{p s - 3 s n d f}_{\text {) }}$ as the proportion of NDF retained on 2 and 3 sieves of the PSPS.

\section{Statistical Analyses}

The data were analyzed using the mixed model procedure of SAS (SAS Institute, 1996) to account for effects of square, period within square, cow within square, and treatment. The treatment was considered a fixed effect; square, period within square, and cow within square were considered random effects. Estimation method was restrictive maximum likelihood (REML) and the degrees of freedom method was Kenward-Rogers. Data for feeding behavior, chewing activity, and ruminal $\mathrm{pH}$ were summarized by day and then analyzed using the same mixed model but with day included as a repeated measure using compound symmetry. Similarly, data for VFA and ammonia were analyzed by sampling time using repeated measures techniques. Data for particle distribution, pef, and peNDF of forages and diets were averaged by period and analyzed by including particle length as a fixed effect and period as a random effect. Linear and quadratic orthogonal contrasts were tested using the CONTRAST statement of SAS. Pearson correlation coefficients were estimated using the CORR procedure of SAS. Effects of the factors were declared significant at $P<0.05$ unless otherwise noted; trends were discussed at $P<0.15$. 


\section{RESULTS AND DISCUSSION}

\section{Silage and Diet Composition}

The silages were well preserved based on the fermentation parameters and the lack of visual signs of spoilage (Table 1). Overall, the silages were very similar in nutrient profiles, even though there were some small statistically significant differences detected. Specifically, contents of DM, NDF, and ADF of CS were quadratically affected by TCL with no effect on starch and CP contents. Higher DM content of medium-cut CS compared with long- and short-cut CS was unexpected because it was harvested first. Reduced TCL of CS from long to medium tended to decrease $\mathrm{NDF}(P<0.06)$ and $\mathrm{ADF}(P<0.11)$ contents, with no further reduction in NDF and a small increase in ADF content as TCL was reduced from medium to short. Decreased NDF content by decreasing TCL of CS was reported in several studies (Bal et al., 2000; Schwab et al., 2002). However, those studies also reported a concomitant change in starch concentration that was not observed in the present study. It is likely that the observed variations in nutrient content of CS were caused by sampling. In support of this theory, Bal et al. (2000) noted that sampling was more uniform for finely chopped CS than for longer chopped silage. Variations in chemical composition of the diets reflected those of the CS used because the diets differed in the TCL of CS (Table 2).

\section{Particle Length and Physically Effective Fiber}

As expected, the values for pef and peNDF obtained using the PSPS with 3 sieves pef $_{\mathrm{ps}-3 \mathrm{~s}}$, peNDF $\mathrm{ps}_{\mathrm{ps}}$, and peNDF $\left.{ }_{\mathrm{ps}-3 \mathrm{sndf}}\right)$ were greater than those obtained using 2 sieves $\left(\right.$ pef $_{\mathrm{ps}-2 \mathrm{~s}}, \mathrm{peNDF}_{\mathrm{ps}-2 \mathrm{~s}}$, and peNDF $\mathrm{ps}_{\mathrm{ps}-2 \mathrm{sndf}}$ ), because of the materials retained on the $1.18-\mathrm{mm}$ sieve (Table 3). In general, particle size distribution, pef, and peNDF of CS measured using the PSPS with either 2 or 3 sieves decreased linearly or quadratically with decreased TCL. However, there was a much smaller range in pef of CS when 3 sieves, rather than 2 , were used (range of 0.93 to 0.96 vs. 0.41 to 0.72 ). As a result, the range in peNDF $\mathrm{ps}_{\text {-2s }}$ and peNDF $\mathrm{ps}_{\text {ssndf }}$ with decreasing TCL of $\mathrm{CS}$ was greater than that of peNDF $\mathrm{ps}_{\mathrm{ss}}$ and $\mathrm{peNDF}_{\mathrm{ps}-}$ 3sndf. Thus, using the PSPS with 3 sieves, expressed on the basis of proportion DM or NDF, did not greatly differentiate the peNDF content of diets varying in chop length of silage.

The present results are in agreement with other reports that used the new PSPS to measure particle distribution of CS. Soita et al. (2005) reported that almost all (99\%) the sample was retained by the PSPS when the 1.18-mm sieve was used, and furthermore, there was no differentiation between long- $(19.1 \mathrm{~mm})$ and short- $(9.5 \mathrm{~mm})$ cut CS. Similarly, no difference in pef was obtained for long- $(22.3 \mathrm{~mm})$ and short- $(4.8 \mathrm{~mm})$ cut CS in the study by Kononoff and Heinrichs (2003b). In contrast, distinct differences in pef were observed for alfalfa hay measured using the new PSPS for forages with a TCL of 19, 10, and $2 \mathrm{~mm}$ (Yansari et al., 2004). It appears that the new PSPS may not be suitable for determining the pef of some forages, including CS.

The higher values for peNDF when expressed on the basis of fractional NDF (peNDF ${ }_{\mathrm{ps}-2 \mathrm{sndf}}$ and $\mathrm{peNDF}_{\mathrm{ps}-}$ 3sndf) than on the basis of total NDF (peNDF ${ }_{\mathrm{ps}-2 \mathrm{~s}}$ or $\mathrm{peNDF}_{\mathrm{ps}-3 \mathrm{~s}}$ ) were expected due to the higher NDF content of the material on the 19- and 8-mm sieves relative to the total NDF content of CS (Kononoff and Heinrichs, 2003b).

Quadratic effects of TCL on pef and peNDF indicated that the increase in the proportion retained on the 19and $8-\mathrm{mm}$ sieves was substantial from short $(4.8 \mathrm{~mm})$ to medium $(15.9 \mathrm{~mm})$ cut, but there was virtually no further increase for further increasing TCL from medium to long $(28.6 \mathrm{~mm})$ cut. In fact, Kononoff and Heinrichs $\left(2003 \mathrm{~b}\right.$ ) reported an $18 \%$ increase in pef $_{\mathrm{ps}-2 \mathrm{~s}}$ (from 0.72 to 0.85 ) for CS when TCL increased from 4.8 to 22.3 $\mathrm{mm}$, whereas there was no increase in the proportion of long particles (retained by an $8.98-\mathrm{mm}$ sieve) when the TCL of CS increased from 19 to $32 \mathrm{~mm}$ (Onetti et al., 2003).

The PSPS pef 1.18 $_{18}$ measured using dry sieving with a vertical oscillating sieve shaker, was also quadratically increased $(P<0.06)$ with increasing TCL of CS, but pef $_{1.18}$ was lower than pef ${ }_{\text {ps-3s }}$, especially for short-cut CS. Yansari et al. (2004) also found that estimates of pef $_{1.18}$ and pef $f_{\text {ps-3s }}$ were different for CS (pef $f_{1.18}$ vs. pef $f_{\text {ps- }}$ 3s; 0.83 vs. 0.92 ), even though estimates were similar for alfalfa hay. Although both these systems of measuring pef incorporate a sieve with mesh size of $1.18 \mathrm{~mm}$, the PSPS sieve consists of nonadjacent round openings, whereas the sieve used with the oscillating shaker consists of adjacent square holes that allow particles to tip through on the diagonal. Thus, longer particles are expected to pass through the $1.18-\mathrm{mm}$ sieve of the oscillating shaker compared with the $1.18-\mathrm{mm}$ sieve of the PSPS, accounting for the differences in pef values obtained using these 2 techniques. Consequently, the pef $_{1.18}$ differentiated the CS of varying TCL to a greater extent that did the PSPS with 3 sieves.

For the diets offered, particle size distribution, pef, and peNDF reflected the variations in TCL of the CS (Table 4). As observed with CS, the proportion of the TMR retained on the 19- and 8-mm sieves, and pef $_{\mathrm{ps}-2 \mathrm{~s}}$ was substantially increased from the low to the medium peNDF diets and then moderately increased from the medium to the high peNDF diets. In contrast, the increase of pef $_{\mathrm{ps}-3 \mathrm{~s}}$ with increasing dietary peNDF was 
Table 4. Particle size distribution, physical effectiveness factors (pef), and physically effective fiber (peNDF) contents of diets

\begin{tabular}{|c|c|c|c|c|c|c|}
\hline \multirow[b]{2}{*}{ Item } & \multicolumn{3}{|c|}{ Dietary peNDF } & \multirow[b]{2}{*}{$\mathrm{SE}$} & \multicolumn{2}{|c|}{ Effects } \\
\hline & Long & Medium & Short & & Linear & Quadratic \\
\hline \multicolumn{7}{|l|}{ PSPS $^{1}$} \\
\hline \multicolumn{7}{|l|}{$\% \mathrm{DM}$ retained on sieves } \\
\hline $19 \mathrm{~mm}$ & 7.6 & 4.8 & 2.3 & 0.4 & 0.01 & NS \\
\hline $8 \mathrm{~mm}$ & 47.9 & 43.7 & 29.9 & 2.4 & 0.01 & 0.03 \\
\hline $1.18 \mathrm{~mm}$ & 33.8 & 38.6 & 52.8 & 1.4 & 0.01 & 0.01 \\
\hline Pan & 10.7 & 12.9 & 15.0 & 1.1 & 0.01 & NS \\
\hline pef $_{\mathrm{ps}-2 \mathrm{~s}}$ & 0.56 & 0.49 & 0.32 & 0.02 & 0.01 & 0.01 \\
\hline pef $f_{\mathrm{ps}-3 \mathrm{~s}}$ & 0.89 & 0.87 & 0.85 & 0.01 & 0.01 & NS \\
\hline $\mathrm{peNDF}_{\mathrm{ps}-2 \mathrm{~s}}, \%$ of DM & 17.6 & 14.8 & 10.0 & 0.7 & 0.01 & 0.06 \\
\hline peNDF ${ }_{\text {ps-2sndf }}, \%$ of DM & 22.2 & 18.8 & 11.9 & 0.9 & 0.01 & 0.03 \\
\hline peNDF $_{\mathrm{ps}-3 \mathrm{~s}}, \%$ of DM & 28.3 & 26.6 & 26.5 & 0.5 & 0.06 & NS \\
\hline $\mathrm{peNDF}_{\mathrm{ps}-3 \mathrm{~s} n d f}, \%$ of DM & 34.1 & 32.3 & 32.4 & 0.8 & NS & NS \\
\hline \multicolumn{7}{|l|}{ Dry sieving ${ }^{2}$. } \\
\hline$\% \mathrm{DM}$ retained on sieve & & & & & & \\
\hline $9.5 \mathrm{~mm}$ & 9.9 & 5.8 & 4.1 & 1.5 & 0.02 & NS \\
\hline $6.7 \mathrm{~mm}$ & 11.1 & 14.4 & 9.1 & 3.6 & NS & NS \\
\hline $3.35 \mathrm{~mm}$ & 24.6 & 26.3 & 22.5 & 2.2 & NS & NS \\
\hline $1.18 \mathrm{~mm}$ & 33.0 & 34.4 & 40.3 & 1.7 & 0.03 & NS \\
\hline $0.6 \mathrm{~mm}$ & 11.6 & 10.3 & 14.5 & 1.2 & 0.12 & 0.10 \\
\hline $0.15 \mathrm{~mm}$ & 6.2 & 5.6 & 7.3 & 1.3 & NS & NS \\
\hline$<0.15 \mathrm{~mm}$ & 3.6 & 3.2 & 2.1 & 0.4 & 0.03 & NS \\
\hline pef $_{1.18}$ & 0.79 & 0.81 & 0.76 & 0.03 & NS & NS \\
\hline $\operatorname{peNDF}_{1.18}, \%$ & 24.9 & 24.7 & 23.7 & 0.9 & NS & NS \\
\hline
\end{tabular}

${ }^{1}$ Particle size distribution of diets was measured using the Penn State Particle Separator (Kononoff et al., 2003a); pef ps-2s $_{\text {and }}$ aef ${ }_{\mathrm{ps}-3 \mathrm{~s}}=$ physical effectiveness factor determined as the proportion of particles retained on 2 sieves (Lammers et al., 1996) and on 3 sieves (Kononoff et al., 2003a), respectively; peNDF ps${ }_{2 \mathrm{~s}}$ and $\mathrm{peNDF}_{\mathrm{ps}-3 \mathrm{~s}}=$ physically effective NDF determined as dietary NDF content multiplied by pef $f_{\mathrm{ps}-2 \mathrm{~s}}$ and pef $_{\mathrm{ps}-3 \mathrm{~s}}$, respectively; peNDF $\mathrm{ps}_{2 \mathrm{sndf}}$ and $\mathrm{peNDF}_{\mathrm{ps}-3 \mathrm{sndf}}=$ proportion of NDF retained on 2 sieves (Lammers et al., 1996) or on 3 sieves (Kononoff et al., 2003a), respectively.

${ }^{2}$ Particle size distribution of diets was measured by dry sieving using a vertical oscillating sieve shaker (Analysette 3; Fritsch, Oberstein, Germany) equipped with a stack of sieves (W. S. Tyler, Inc., Mentor, OH)

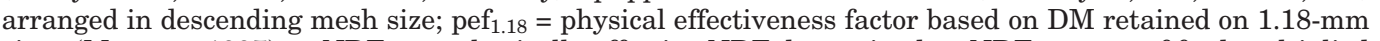
sieve (Mertens, 1997); peNDF $_{1.18}$ = physically effective NDF determined as NDF content of feed multiplied by pef $_{1.18}$.

$\mathrm{NS}=P>0.15$.

small with only a difference $(P<0.06)$ detected between the medium and high peNDF diets. These data confirm the study of Kononoff and Heinrichs (2003b) in which dietary peNDF $\mathrm{ps}_{\mathrm{ps}}$ contents were similar even though the proportion of CS in the diets varied from 45 to $57 \%$. In contrast, with diets containing alfalfa hay, dietary $\mathrm{peNDF}_{\mathrm{ps}-3 \mathrm{~s}}$ contents were increased from 17.2 to 22.6 to $25.1 \%$ for diets containing fine, medium, and long hay, respectively (Yansari et al., 2004). It appears that the new PSPS may not adequately measure the pef of CS-based diets, although it may distinguish the pef of hay-based diets. In our study, values for dietary pef $f_{1.18}$ and peNDF ${ }_{1.18}$ contents were intermediate of the 3 systems used, but the values did not differentiate among diets formulated using CS varying in TCL. Thus, peNDF values obtained using a 1.18 -mm sieve, either as part of the PSPS or alone, do not adequately reflect differences in particle length of diets containing CS of varying TCL.
Estimates of dietary peNDF content based on fractional NDF retention on sieves $\left(\mathrm{peNDF}_{\mathrm{ps}-2 \mathrm{sndf}}\right.$ and peNDF $_{\text {ps-3sndf }}$ ) were on average 4 to 6 units higher than those calculated using the NDF content of the diet (peNDF ${ }_{\mathrm{ps}-2 \mathrm{~s}}$ and peNDF $\mathrm{ps}_{\mathrm{ps}}$ ). This difference was caused by the higher NDF content of the material retained on the 19- and 8-mm sieves compared with the overall NDF content of the diet (Kononoff and Heinrichs, 2003a). The magnitude of increase in dietary peNDF values due to switching from total NDF to fractional NDF was consistent across the treatments and was generally not affected by forage particle size in the diets. Therefore, replacing the total NDF with the fractional NDF to estimate dietary peNDF (i.e., peNDF $\mathrm{ps-2sndf}_{\text {or }}$ peNDF $\mathrm{Ns-}_{\text {- }}$ 3sndf) did not change the ranking of the diets based on peNDF content, but increased the cost of analysis. However, the degree to which dietary peNDF values are increased when using fractional NDF rather than total NDF to estimate peNDF will depend upon the propor- 
Table 5. Effects of reducing dietary physically effective fiber (peNDF) on intake and digestibility of nutrients in the total tract of lactating dairy cows

\begin{tabular}{|c|c|c|c|c|c|c|}
\hline \multirow[b]{2}{*}{ Item } & \multicolumn{3}{|c|}{ Dietary peNDF } & \multirow[b]{2}{*}{$\mathrm{SE}$} & \multicolumn{2}{|c|}{ Effects } \\
\hline & Long & Medium & Short & & Linear & Quadratic \\
\hline \multicolumn{7}{|l|}{ Intake } \\
\hline $\mathrm{DM}, \mathrm{kg} / \mathrm{d}$ & 23.7 & 23.8 & 24.8 & 1.0 & NS & NS \\
\hline $\mathrm{DM}, \%$ of BW & 3.48 & 3.45 & 3.64 & 0.13 & NS & NS \\
\hline $\mathrm{OM}, \mathrm{kg} / \mathrm{d}$ & 22.0 & 22.1 & 23.0 & 0.9 & NS & NS \\
\hline $\mathrm{NDF}, \mathrm{kg} / \mathrm{d}$ & 7.5 & 7.3 & 7.8 & 0.3 & NS & 0.12 \\
\hline $\begin{array}{l}\text { Forage NDF, kg/d } \\
\text { peNDF, }{ }^{1} \mathrm{~kg} / \mathrm{d}\end{array}$ & 5.4 & 5.0 & 5.4 & 0.2 & NS & 0.08 \\
\hline peNDF $_{1.18}$ & 5.9 & 5.9 & 5.9 & 0.3 & NS & NS \\
\hline $\mathrm{peNDF}_{\mathrm{ps}-2 \mathrm{~s}}$ & 4.2 & 3.5 & 2.5 & 0.2 & 0.01 & NS \\
\hline peNDF ${ }_{\text {ps-2sndf }}$ & 5.3 & 4.5 & 2.6 & 0.2 & 0.01 & 0.02 \\
\hline peNDF ${ }_{\mathrm{ps}-3 \mathrm{~s}}$ & 6.7 & 6.3 & 6.6 & 0.3 & NS & NS \\
\hline peNDF $_{\mathrm{ps}-3 \text { sndf }}$ & 8.1 & 7.7 & 8.0 & 0.3 & NS & NS \\
\hline $\mathrm{ADF}, \mathrm{kg} / \mathrm{d}$ & 3.7 & 3.1 & 3.8 & 0.2 & NS & 0.01 \\
\hline Starch, kg/d & 9.4 & 9.2 & 9.4 & 0.5 & NS & NS \\
\hline $\mathrm{CP}, \mathrm{kg} / \mathrm{d}$ & 4.2 & 4.1 & 4.2 & 0.2 & NS & NS \\
\hline $\mathrm{BW}, \mathrm{kg}$ & 686 & 695 & 683 & 32 & NS & 0.08 \\
\hline \multicolumn{7}{|c|}{ Digestibility, $\%$ of intake } \\
\hline DM & 65.1 & 64.5 & 63.2 & 1.3 & NS & NS \\
\hline $\mathrm{OM}$ & 66.6 & 66.0 & 65.4 & 1.3 & NS & NS \\
\hline $\mathrm{NDF}$ & 50.5 & 47.6 & 45.7 & 2.5 & 0.15 & NS \\
\hline $\mathrm{ADF}$ & 49.4 & 45.0 & 43.9 & 3.5 & 0.11 & NS \\
\hline Starch & 82.9 & 81.7 & 84.4 & 1.7 & NS & NS \\
\hline $\mathrm{CP}$ & 65.7 & 66.2 & 61.3 & 1.2 & 0.03 & 0.09 \\
\hline
\end{tabular}

${ }_{1}^{1}$ peNDF $_{118}$, peNDF $_{\mathrm{ps}-2 \mathrm{~s}}$, and peNDF $\mathrm{ps}_{3 \mathrm{~s}}=$ physically effective NDF determined as NDF content of diets multiplied by pef $f_{1.18}$, pef $_{\mathrm{ps}-2 \mathrm{~s}}$, and pef $\mathrm{ps}_{\mathrm{s}-3 \mathrm{~s}}$, respectively; peNDF $\mathrm{ps}_{2 \mathrm{sndf}}$ and peNDF $\mathrm{ps}_{\text {-3sndf }}=$ proportion of $\mathrm{NDF}$ retained on 2 sieves (Lammers et al., 1996) or on 3 sieves (Kononoff et al., 2003a), respectively.

$\mathrm{NS}=P>0.15$.

tion of concentrate in the diet. Einarson et al. (2004) reported that peNDF ${ }_{\mathrm{ps}-2 \mathrm{sndf}}$ was higher than $\mathrm{peNDF}_{\mathrm{ps}-}$ ${ }_{2 \mathrm{~s}}$ by $35 \%$ in high concentrate (58\%) and by $21 \%$ in low concentrate $(40 \%)$ diets because the uniformity of NDF distribution decreases with increasing concentrate proportion of diet. Methods of estimating peNDF that use pef $_{\text {ps-2s }}$, pef $_{\mathrm{ps}-3 \mathrm{~s}}$, or pef $f_{1.18}$ are based on the assumption that NDF is uniformly distributed over all particle sizes. Hence, the peNDF content of high concentrate diets can be underestimated relative to low concentrate diets using methods that do not correct for fractional NDF content ( $\operatorname{peNDF}_{\mathrm{ps}-2 \mathrm{~s}}, \mathrm{peNDF}_{\mathrm{ps}-3 \mathrm{~s}}$, or $\mathrm{peNDF}_{1.18}$ ).

\section{Intake, Digestibility, and Microbial Production}

Intake of DM (kg/d or \% of BW) was not affected by diet (Table 5). Several studies (Bal et al., 2000; Soita et al., 2005; Yang and Beauchemin, 2005) have indicated a lack of effect of chop length on DMI of dairy cows consuming CS with TCL ranging from 9 to $19 \mathrm{~mm}$. However, other studies have reported a decrease in DMI of dairy cows when TCL of CS was increased which can be explained by increased rumen retention time of feed resulting in increased rumen fill and reduced intake. However, increased rumen retention time is not always the case. For example, Schwab et al. (2002) did not observe an increase of rumen retention time of feed although DMI was reduced by $0.8 \mathrm{~kg} / \mathrm{d}$ when the TCL of CS was increased from 19 to $32 \mathrm{~mm}$. The DMI was also reduced when the TCL of CS was increased from 13 to $19 \mathrm{~mm}$ in that study. Furthermore, De Boever et al. (1993) reported a $1.4 \mathrm{~kg} / \mathrm{d}$ reduction in DMI when TCL of CS was increased from 4 to $8 \mathrm{~mm}$. It appears that the effect of the TCL of CS on DMI is not consistent, which may relate to the inconsistent effect of increased TCL of forages on the peNDF content of the diets. In the present study, increasing the TCL of CS from 15.9 to $28.6 \mathrm{~mm}$ did not greatly increase the proportion of coarse forage particles or the peNDF content of the diets.

Intakes of starch and CP were not affected by dietary peNDF. Therefore, lower intake of ADF and the trend toward lower $(P<0.12)$ intake of NDF for the medium peNDF diet was attributed to its lower concentration of $\mathrm{NDF}$ and ADF compared with the high and low peNDF diets. As expected, consumption of peNDF followed the same trend as peNDF contents of the diets; intakes of peNDF using the PSPS with 2 sieves $\left(\mathrm{peNDF}_{\mathrm{ps}-2 \mathrm{~s}}\right.$ and peNDF $F_{\mathrm{ps}-2 \mathrm{sndf}}$ ) linearly increased with increasing dietary peNDF, whereas there were no differences in intakes of peNDF when measured using a system that 
incorporates a $1.18-\mathrm{mm}$ sieve $\left(\mathrm{peNDF}_{1.18}, \mathrm{peNDF}_{\mathrm{ps}-3 \mathrm{~s}}\right.$, and peNDF $_{\text {ps-3sndf }}$.

Apparent digestibilities of DM, OM, and starch in the total tract were unaffected by dietary peNDF, whereas increasing dietary peNDF linearly increased digestibility of CP and tended to increase digestibilities of NDF $(P<0.15)$ and ADF $(P<0.11$; Table 5$)$. These results are in agreement with some reports (Bal et al., 2000; Schwab et al., 2002; Yang and Beauchemin, 2005) but are in contrast to others (Kononoff and Heinrichs, 2003b; Fernandez et al., 2004) for cows fed CS-based diets. The discrepancy in effects of peNDF on nutrient digestibility in the total tract across the studies is attributed to various dietary factors. Chopping forage finely increases surface area available for microbial attack thereby accelerating digestion, but fine particles often have faster passage rate from the rumen such that digestibility is reduced. In addition, long particles are reduced in size during ingestive mastication, thereby eliminating the effects of particle length. Fernandez and Michalet-Doreau (2002) reported that mean particle length markedly decreased after ingestive mastication, and the decrease was greater for coarsely chopped than for finely chopped CS. Fermentability of concentrate could be another factor influencing digestion. In our previous study (Yang and Beauchemin, 2005) using a barley grain-based diet, total digestibility was increased with increasing dietary peNDF. However, when using a corn grain-based diet in the present study, the increase of digestibility in the total tract was minimal with increasing TCL of CS. Dietary particle length may enhance ruminal fermentation to a greater extent for barley-based diets than for corn-based diets because barley is rapidly degradable in the rumen following ingestion. Similarly, an increase of fiber digestion in the total tract with increasing particle length of CS was reported when processed CS (Bal et al., 2000; Schwab et al., 2002; Yang and Beauchemin, 2005), rather than unprocessed CS (Kononoff and Heinrichs, 2003b; Fernandez et al., 2004), was fed because processing increases ruminal starch digestibility (Schwab et al., 2002).

Daily urinary excretion of uric acid and allantoin was higher with the medium dietary peNDF than with the high or low dietary peNDF, so that urinary excretion of total PD was higher with the medium peNDF diet (Table 6). Consequently, calculated intestinal flow of microbial $\mathrm{N}(\mathrm{g} / \mathrm{d})$ and microbial efficiency $(\mathrm{g} / \mathrm{kg}$ of digestible OM intake) were quadratically increased with increasing dietary peNDF. The microbial N supply estimated in the present study was similar to that obtained by Krause and Combs (2003), who estimated microbial $\mathrm{N}$ supply using the same procedure from diets based on alfalfa silage, corn silage, and corn grain, and found an average microbial N supply of $297.7 \mathrm{~g} / \mathrm{d}$. Krause et al. (2002a) reported that ruminally fermentable carbohydrate is the key dietary factor affecting microbial protein synthesis, whereas dietary particle size indirectly influences microbial protein synthesis by its effects on feed intake. In the present study, lower microbial N supply for the high peNDF than for the medium peNDF diet could be due to lower starch digestion in the rumen resulting from a shift in starch digestion to the intestine with high peNDF (Yang and Beauchemin, 2005). Lower microbial N supply with low dietary peNDF is in agreement with our previous study (Yang and Beauchemin, 2005) in which microbial protein synthesis was decreased with decreasing dietary peNDF due to lower nutrient digestion in the rumen. Digestibilities of protein and fiber $(P<0.15)$ in the total tract were linearly lowered by reducing the dietary peNDF in the present study (Table 5).

\section{Milk Yield and Composition}

Actual milk yield was lower $(P<0.08)$ for the low than for the medium and high peNDF diets, but $4 \%$ FCM was similar across treatments (Table 7). The lower milk yield of the cows fed the low peNDF diet was consistent with the lower digestibilities of protein and fiber in the total tract and the lower microbial protein synthesis. In animal digestion studies, the milk yield response to dietary peNDF is usually minimal (Zebeli et al., 2006) because most studies are conducted using few cows with short experimental periods (e.g., $21 \mathrm{~d}$ ). Furthermore, the cows used in the present study, were quite variable in stage of lactation, ranging from 60 to 180 DIM, which could account for some of the variability in response to the treatments.

Milk fat and protein percentages and yields were not affected by dietary peNDF, and milk lactose content and yield only tended to be higher $(P<0.10)$ with the medium than with the high or low dietary peNDF (Table 7). Lack of effect of dietary peNDF on milk fat content suggests that the diets contained adequate fiber to maintain milk fat percentage above $3.5 \%$. The contents of dietary NDF (31.1\%) and NDF from forage $(21.9 \%)$ in the current study were above the minimum recommendation by NRC (2001). Beauchemin and Rode (1997) reported a depression of milk fat when NDF was below minimum requirements. Using the peNDF system, Kononoff and Heinrichs (2003b) reported a tendency $(P<0.10)$ for lower milk fat percentage with peNDF ${ }_{\mathrm{ps}-2 \mathrm{~s}}$ and $\mathrm{peNDF}_{\mathrm{ps}-3 \mathrm{~s}}$ decreasing from 18.4 to $15.6 \%$ and from 30.6 to $32.4 \%$, respectively. However, Yansari et al. (2004) reported a 10\% reduction in milk fat percentage when dietary peNDF ${ }_{\mathrm{ps}-2 \mathrm{~s}}$ decreased from 11.2 to $2.0 \%$ and peNDF $_{\mathrm{ps}-3 \mathrm{~s}}$ decreased from 25.1 to 
Table 6. Effects of reducing dietary physically effective fiber (peNDF) on urinary purine derivative excretion and ruminal microbial $\mathrm{N}$ synthesis of lactating dairy cows

\begin{tabular}{|c|c|c|c|c|c|c|}
\hline \multirow[b]{2}{*}{ Item } & \multicolumn{3}{|c|}{ Dietary peNDF } & \multirow[b]{2}{*}{ SE } & \multicolumn{2}{|c|}{ Effects } \\
\hline & Long & Medium & Short & & Linear & Quadratic \\
\hline \multicolumn{7}{|l|}{ Urinary excretion, $\mathrm{mmol} / \mathrm{d}$} \\
\hline Uric acid & 38.5 & 41.7 & 41.9 & 5.5 & NS & NS \\
\hline Allantoin & 333.2 & 367.3 & 320.4 & 26.9 & NS & 0.05 \\
\hline Total & 371.7 & 409.0 & 362.3 & 30.1 & NS & 0.03 \\
\hline Absorption, mmol/d & 437.3 & 481.2 & 426.2 & 35.4 & NS & 0.03 \\
\hline \multicolumn{7}{|l|}{ Microbial protein synthesis } \\
\hline $\mathrm{N}, \mathrm{g} / \mathrm{d}$ & 291.0 & 317.3 & 280.0 & 25.0 & NS & 0.02 \\
\hline $\mathrm{N}, \mathrm{g} / \mathrm{kg}$ of digestible $\mathrm{OM}$ intake & 19.7 & 21.9 & 18.9 & 1.6 & NS & 0.05 \\
\hline
\end{tabular}

$\mathrm{NS}=P>0.15$.

$17.2 \%$. Hence, results from the literature and the present study support the recommendation of $19.7 \%$ peNDF $_{1.18}$ by Mertens (1997) to maintain a milk fat of $3.4 \%$ as well as the suggestion of Beauchemin and Yang (2005) that a level of dietary peNDF $\mathrm{ps}_{-2 \mathrm{~s}}$ above $10 \%$ is required to avoid a reduction of chewing activity.

\section{Chewing Activity}

Increasing peNDF content of the diet tended to decrease the number of eating chews per unit of DMI $(P$ $<0.10)$ or NDF intake $(P<0.08)$, but did not affect the numbers of ruminating chews (Table 8 ). Cows spent similar time eating the high, medium, and low peNDF diets. However, ruminating time, as well as total chewing time, was linearly increased with increasing dietary peNDF. A tendency to reduce the number of eating chews with no difference in eating time for increasing dietary peNDF was not expected and contrasts with the literature (Fischer et al., 1994; Beauchemin and Yang, 2005). In those studies, although eating time was similar, number of chews per kilogram of DMI during eating was linearly increased $(P<0.10)$ with increasing dietary peNDF. The increase in total chewing time due to increased dietary peNDF resulted from increased ruminating time rather than eating time, which is consistent with some reports (Kononoff and Heinrichs, 2003b; Kononoff et al., 2003b), but different from others (Soita et al., 2000; Kononoff and Heinrichs, 2003a; Beauchemin and Yang, 2005) in which both eating and ruminating times were increased. Thus, increasing peNDF typically increases chewing time, mainly because of increased rumination time, and in some cases, increased eating time as well.

Chewing index, expressed as the ratio of total chewing activity to feed intake, was not affected by dietary peNDF when based on DMI (min/kg of DM) or NDF intake ( $\mathrm{min} / \mathrm{kg}$ of NDF), and averaged 29.2 and 93.7 , respectively (Table 8). The values are consistent with those of Kononoff and Heinrichs (2003b), but different from other reports (Kononoff et al., 2003b; Beauchemin and Yang, 2005) for CS-based diets. Mertens (1997)

Table 7. Effects of reducing dietary physically effective fiber (peNDF) on yield and composition of milk of lactating dairy cows

\begin{tabular}{|c|c|c|c|c|c|c|}
\hline \multirow[b]{2}{*}{ Item } & \multicolumn{3}{|c|}{ Dietary peNDF } & \multirow[b]{2}{*}{$\mathrm{SE}$} & \multicolumn{2}{|c|}{ Effects } \\
\hline & Long & Medium & Short & & Linear & Quadratic \\
\hline \multicolumn{7}{|l|}{ Milk yield, $\mathrm{kg} / \mathrm{d}$} \\
\hline Actual & 32.1 & 32.4 & 31.5 & 2.4 & 0.08 & 0.04 \\
\hline $4 \% \mathrm{FCM}$ & 30.1 & 30.7 & 29.5 & 2.7 & NS & NS \\
\hline \multicolumn{7}{|l|}{ Milk fat } \\
\hline$\%$ & 3.65 & 3.66 & 3.65 & 0.20 & NS & NS \\
\hline $\mathrm{kg} / \mathrm{d}$ & 1.15 & 1.18 & 1.13 & 0.13 & NS & NS \\
\hline \multicolumn{7}{|l|}{ Milk protein } \\
\hline$\%$ & 3.30 & 3.23 & 3.24 & 0.13 & NS & NS \\
\hline $\mathrm{kg} / \mathrm{d}$ & 1.04 & 1.04 & 1.01 & 0.08 & NS & NS \\
\hline \multicolumn{7}{|l|}{ Milk lactose } \\
\hline$\%$ & 4.37 & 4.47 & 4.44 & 0.15 & NS & 0.10 \\
\hline $\mathrm{kg} / \mathrm{d}$ & 1.41 & 1.45 & 1.40 & 0.14 & NS & 0.06 \\
\hline Milk/DMI & 1.37 & 1.37 & 1.28 & 0.13 & NS & NS \\
\hline FCM/DMI & 1.28 & 1.31 & 1.20 & 0.11 & NS & NS \\
\hline $\mathrm{SCC}, \times 10^{5}$ cell $\mathrm{s} / \mathrm{mL}$ & 3.89 & 4.84 & 5.65 & 1.83 & NS & NS \\
\hline
\end{tabular}

$\mathrm{NS}=P>0.15$. 
Table 8. Effects of reducing dietary physically effective fiber (peNDF) on chewing activity of lactating dairy cows

\begin{tabular}{|c|c|c|c|c|c|c|}
\hline \multirow[b]{2}{*}{ Item } & \multicolumn{3}{|c|}{ Dietary peNDF } & \multirow[b]{2}{*}{$\mathrm{SE}$} & \multicolumn{2}{|c|}{ Effects } \\
\hline & Long & Medium & Short & & Linear & Quadratic \\
\hline \multicolumn{7}{|l|}{ Eating } \\
\hline Chews/d & 16,266 & 17,348 & 17,310 & 1,251 & NS & NS \\
\hline Chews/kg of DM & 662 & 714 & 788 & 82 & 0.10 & NS \\
\hline Chews/kg of NDF & 2,081 & 2,335 & 2,502 & 240 & 0.08 & NS \\
\hline $\mathrm{Min} / \mathrm{d}$ & 240.2 & 234.2 & 231.6 & 14.0 & NS & NS \\
\hline $\mathrm{Min} / \mathrm{kg}$ of $\mathrm{DM}$ & 9.7 & 9.7 & 10.2 & 0.6 & NS & NS \\
\hline $\mathrm{Min} / \mathrm{kg}$ of $\mathrm{NDF}$ & 30.7 & 31.7 & 32.5 & 2.2 & NS & NS \\
\hline $\mathrm{Min} / \mathrm{kg}$ of $\mathrm{peNDF}_{1.18}{ }^{1}$ & 39.1 & 39.3 & 43.0 & 2.6 & 0.14 & NS \\
\hline $\mathrm{Min} / \mathrm{kg}$ of $\mathrm{peNDF} \mathrm{ps}-2 \mathrm{~s}$ & 55.3 & 65.2 & 102.6 & 5.4 & 0.01 & 0.03 \\
\hline $\mathrm{Min} / \mathrm{kg}$ of $\mathrm{peNDF} \mathrm{ps}_{\mathrm{ps}}{ }^{1}$ & 36.1 & 37.0 & 35.2 & 2.2 & NS & NS \\
\hline \multicolumn{7}{|l|}{ Ruminating } \\
\hline Chews/d & 29,511 & 28,317 & 25,412 & 2,111 & NS & NS \\
\hline Chews/kg of DM & 1,199 & 1,176 & 1,129 & 109 & NS & NS \\
\hline Chews/kg of NDF & 3,772 & 3,852 & 3,586 & 318 & NS & NS \\
\hline $\mathrm{Min} / \mathrm{d}$ & 507.7 & 462.7 & 410.6 & 32.3 & 0.03 & NS \\
\hline Min/kg of DM & 20.6 & 19.3 & 18.3 & 1.7 & 0.12 & NS \\
\hline $\mathrm{Min} / \mathrm{kg}$ of $\mathrm{NDF}$ & 64.9 & 63.2 & 58.2 & 4.9 & NS & NS \\
\hline $\mathrm{Min} / \mathrm{kg}$ of $\mathrm{peNDF}_{1.18}{ }^{1}$ & 82.9 & 78.6 & 76.7 & 6.9 & NS & NS \\
\hline $\mathrm{Min} / \mathrm{kg}$ of $\mathrm{peNDF} \mathrm{ps}-2 \mathrm{~s}$ & 117.3 & 129.8 & 184.2 & 14.3 & 0.01 & 0.14 \\
\hline $\mathrm{Min} / \mathrm{kg}$ of $\mathrm{peNDF} \mathrm{ps}_{\mathrm{ps}}{ }^{1}$ & 76.5 & 73.6 & 62.4 & 8.1 & 0.11 & NS \\
\hline \multicolumn{7}{|l|}{ Total chewing } \\
\hline Chews/d & 45,776 & 45,665 & 42,722 & 2,933 & NS & NS \\
\hline Chews/kg of DM & 1,861 & 1,889 & 1,917 & 179 & NS & NS \\
\hline Chews/kg of NDF & 5,853 & 6,186 & 6,088 & 513 & NS & NS \\
\hline $\mathrm{Min} / \mathrm{d}$ & 747.9 & 696.9 & 642.2 & 36.0 & 0.06 & NS \\
\hline Min/kg of DM & 30.3 & 28.9 & 28.5 & 2.2 & NS & NS \\
\hline $\mathrm{Min} / \mathrm{kg}$ of $\mathrm{NDF}$ & 95.6 & 94.9 & 90.7 & 6.4 & NS & NS \\
\hline $\mathrm{Min} / \mathrm{kg}$ of peNDF${ }_{1.18}{ }^{1}$ & 122.0 & 117.9 & 119.7 & 9.0 & NS & NS \\
\hline $\mathrm{Min} / \mathrm{kg}$ of peNDF $\mathrm{ps}_{\mathrm{ps}}{ }^{1}$ & 172.6 & 195.1 & 286.9 & 19.0 & 0.01 & 0.06 \\
\hline $\mathrm{Min} / \mathrm{kg}$ of $\mathrm{peNDF} \mathrm{ps}-3 \mathrm{~s}^{1}$ & 112.6 & 110.5 & 97.6 & 8.7 & 0.10 & 0.14 \\
\hline \multicolumn{7}{|l|}{ Meal patterns } \\
\hline Meals/d & 6.2 & 6.4 & 6.8 & 0.5 & 0.06 & NS \\
\hline Meal size, kg & & & & & & \\
\hline $\mathrm{DM}$ & 4.0 & 3.8 & 3.5 & 0.4 & 0.05 & NS \\
\hline $\mathrm{NDF}$ & 1.3 & 1.2 & 1.1 & 0.1 & 0.05 & NS \\
\hline Intake rate, $\mathrm{g}$ of $\mathrm{DM} / \mathrm{min}$ & 104.7 & 106.2 & 99.6 & 6.5 & NS & NS \\
\hline
\end{tabular}

${ }^{1} \mathrm{peNDF}_{1.18}, \mathrm{peNDF}_{\mathrm{ps}-2 \mathrm{~s}}$, and peNDF $\mathrm{ps}_{\mathrm{ps}}=$ physically effective NDF determined as NDF content of diets multiplied by pef 1.18, pef $_{\text {ps-2s }}$, and pef $f_{\mathrm{ps}-3 \mathrm{~s}}$, respectively.

NS $=P>0.15$.

suggested that the ratio of total chewing activity to DM is an attribute of the feed, for cows of the same genotype, size, and level of intake. Zebeli et al. (2006) reviewed 99 published treatment means and found that cows spent 17.9 to $47.1 \mathrm{~min} / \mathrm{kg}$ of DM and 54.3 to $160.1 \mathrm{~min} /$ $\mathrm{kg}$ of NDF in total chewing, indicating that intake of $\mathrm{DM}$ or NDF is not a reliable variable to predict chewing duration. Furthermore, the chewing index based on intake of peNDF ( $\mathrm{min} / \mathrm{kg}$ of peNDF) was constant among diets with peNDF ${ }_{1.18}$ (118 to 122 ), slightly more variable with $\operatorname{peNDF}_{\mathrm{ps}-3 \mathrm{~s}}(98$ to $113 ; P<0.10)$, and particularly variable with peNDF $\mathrm{ps}_{\mathrm{ps}}$ (173 to 287 ). The implication is that systems of measuring peNDF that incorporate a $1.18-\mathrm{mm}$ sieve $\left(\mathrm{peNDF}_{1.18}\right.$ or $\mathrm{peNDF}_{\mathrm{ps}-3 \mathrm{~s}}$ ) provide a more consistent prediction of the chewing index of the feed than the PSPS with 2 sieves (peNDF $\mathrm{ps}_{-2 \mathrm{~s}}$ ). The present results are consistent with the findings of Yans- ari et al. (2004) who reported for high, medium, and low dietary peNDF, a more consistent chewing index for $\operatorname{peNDF}_{1.18}(120,112$, and 118 , respectively) and for peNDF $_{\mathrm{ps}-3 \mathrm{~s}}(112,105$, and 102, respectively) than for peNDF $_{\mathrm{ps}-2 \mathrm{~s}}(250,409$, and 926, respectively). Values for chewing index $\left(\mathrm{min} / \mathrm{kg}\right.$ of $\mathrm{peNDF}_{\mathrm{ps}-3 \mathrm{~s}}$ ) of CS-based diets reported by Kononoff and Heinrichs (2003b) ranged 82 to 93 and from 71 to 81 in the study by Kononoff et al. (2003b). However, a considerable variation in chewing index based on peNDF 1.18 , ranging from 71 to 644 , was reported for 87 published treatment means (Zebeli et al., 2006). Therefore, none of the current systems of evaluating peNDF provides a consistent measure of chewing activity, although chewing time is generally increased with increasing dietary peNDF content. Because other factors such as animal, level of intake, and type of feed also affect chewing activity, dietary peNDF 
Table 9. Effects of reducing dietary physically effective fiber (peNDF) on ruminal $\mathrm{pH}$ and fermentation of lactating dairy cows

\begin{tabular}{|c|c|c|c|c|c|c|}
\hline \multirow[b]{2}{*}{ Item } & \multicolumn{3}{|c|}{ Dietary peNDF } & \multirow[b]{2}{*}{$\mathrm{SE}$} & \multicolumn{2}{|c|}{ Effects } \\
\hline & Long & Medium & Short & & Linear & Quadratic \\
\hline \multicolumn{7}{|l|}{$\mathrm{pH}$} \\
\hline Mean & 6.08 & 6.06 & 5.99 & 0.05 & NS & NS \\
\hline Area under $\mathrm{pH} 5.8, \mathrm{pH} \times \mathrm{h} / \mathrm{d}$ & 0.72 & 0.84 & 1.39 & 0.5 & NS & NS \\
\hline Area under $\mathrm{pH} 5.5, \mathrm{pH} \times \mathrm{h} / \mathrm{d}$ & 0.16 & 0.13 & 0.38 & 0.2 & NS & NS \\
\hline $\mathrm{pH}<5.8, \mathrm{~h} / \mathrm{d}$ & 3.0 & 4.1 & 4.8 & 1.2 & NS & NS \\
\hline $\mathrm{pH}<5.5, \mathrm{~h} / \mathrm{d}$ & 0.8 & 1.0 & 2.0 & 0.9 & 0.13 & NS \\
\hline Lowest & 5.44 & 5.44 & 5.52 & 0.08 & NS & NS \\
\hline \multicolumn{7}{|l|}{ VFA } \\
\hline Total, $\mathrm{m} M$ & 120.4 & 119.7 & 120.7 & 6.7 & NS & NS \\
\hline Acetate (A), mol/100 mol & 57.6 & 57.8 & 58.5 & 1.4 & NS & NS \\
\hline Propionate $(\mathrm{P}), \mathrm{mol} / 100 \mathrm{~mol}$ & 22.8 & 22.1 & 22.5 & 1.1 & NS & NS \\
\hline Butyrate, $\mathrm{mol} / 100 \mathrm{~mol}$ & 15.5 & 15.6 & 14.8 & 0.9 & NS & NS \\
\hline $\mathrm{A}: \mathrm{P}$ & 2.60 & 2.66 & 2.62 & 0.16 & NS & NS \\
\hline $\mathrm{NH}_{3} \mathrm{~N}, \mathrm{~m} M$ & 8.8 & 9.8 & 10.6 & 0.9 & 0.03 & NS \\
\hline
\end{tabular}

$\mathrm{NS}=P>0.15$.

level may have variable effects on promoting chewing among cows and studies. Furthermore, particle distribution of the feed actually consumed by the cow can differ substantially from that offered due to sorting in favor or against long particles, and this can drastically affect the actual intake of peNDF (Yang and Beauche$\min , 2006$ ).

Number of meals per day tended $(P<0.06)$ to be linearly decreased, but amount of DM and NDF per meal was linearly increased, with increasing dietary peNDF (Table 8). Intake rate (g of DM/min) was similar among the treatments. Linearly increased meal size due to increased dietary peNDF is consistent with the observation of Beauchemin and Yang (2005) who reported that amount of NDF per meal tended $(P<0.13)$ to be higher with higher dietary peNDF. The linearly increased meal size was associated with fewer meals rather than a faster intake rate.

\section{Ruminal $\mathrm{pH}$ and Fermentation}

Ruminal $\mathrm{pH}$ parameters including mean $\mathrm{pH}$, area under $\mathrm{pH} 5.8$ or 5.5 , duration $\mathrm{pH}<5.8$, and the lowest $\mathrm{pH}$ were not affected by dietary peNDF except duration of $\mathrm{pH}<5.5$, which tended $(P<0.13)$ to be linearly reduced with increasing dietary peNDF (Table 9). Reduced duration of $\mathrm{pH}<5.5$ in the rumen indicated a small improvement of ruminal $\mathrm{pH}$ status $(1 \mathrm{~h}$ reduction during a 24-h period). Lack of effect of CS particle size on mean ruminal $\mathrm{pH}$ in the present study is consistent with a number of studies (Kononoff and Heinrichs, 2003b; Plaizier, 2004; Beauchemin and Yang, 2005), although it contrasts with the commonly accepted principle that increasing particle length promotes chewing activity, and thereby increases buffering capacity within the rumen due to increased saliva secretion. Zebeli et al. (2006) conducted a regression analysis by pooling 100 treatment means and showed that mean ruminal $\mathrm{pH}$ responded in a quadratic fashion either to $\mathrm{peNDF}_{1.18}$ or to peNDF $\mathrm{ps}_{-2 \mathrm{~s}}$. The authors further determined that the plateau for ruminal $\mathrm{pH}$ in response to peNDF $_{1.18}$ occurred at $22.6 \%$ dietary peNDF 1.18 . The average dietary peNDF 1.18 of $24.4 \%$ in the present study was above this threshold, which may explain the lack of effect of peNDF on ruminal $\mathrm{pH}$.

Total concentration of VFA and their molar proportion were not affected by dietary peNDF (Table 9). The similar ruminal VFA concentration across the treatments was consistent with the ruminal $\mathrm{pH}$ data. However, there was a linear reduction in ruminal ammonia concentration with increasing dietary peNDF.

\section{Correlations}

Particles retained on the 19- or 8-mm sieves of the PSPS and the dietary peNDF content, regardless of methods used to determine it, were not correlated to the number of chews (Table 10). However, chewing activity $(\mathrm{min} / \mathrm{d})$ was correlated with particles on the 8-mm sieve $(\mathrm{r}=0.52), \mathrm{peNDF}_{\mathrm{ps}-2 \mathrm{~s}}(\mathrm{r}=0.52), \mathrm{peNDF}_{\mathrm{ps}-2 \mathrm{sndf}}(\mathrm{r}=0.49)$, $\operatorname{peNDF}_{\mathrm{ps}-3 \mathrm{~s}}(\mathrm{r}=0.45, P<0.10)$, and $\mathrm{peNDF}_{\mathrm{ps}-3 \mathrm{sndf}}(\mathrm{r}=$ $0.47)$. The positive correlation of dietary peNDF with chewing time is consistent with the linear increase in chewing time with increasing dietary peNDF levels (Table 8). Lack of correlation between peNDF ${ }_{1.18}$ and chewing activity was due to similar dietary peNDF ${ }_{1.18}$ content across the treatments (Table 4). The correlation between particles $>8 \mathrm{~mm}$ and chewing time is in agreement with our previous report (Beauchemin and Yang, 2005), but contrasts with the finding of Kononoff 
FORAGE PARTICLE SIZE FOR DAIRY COWS

Table 10. Pearson correlation coefficients ${ }^{1}$ for parameter measurements among 18 observations

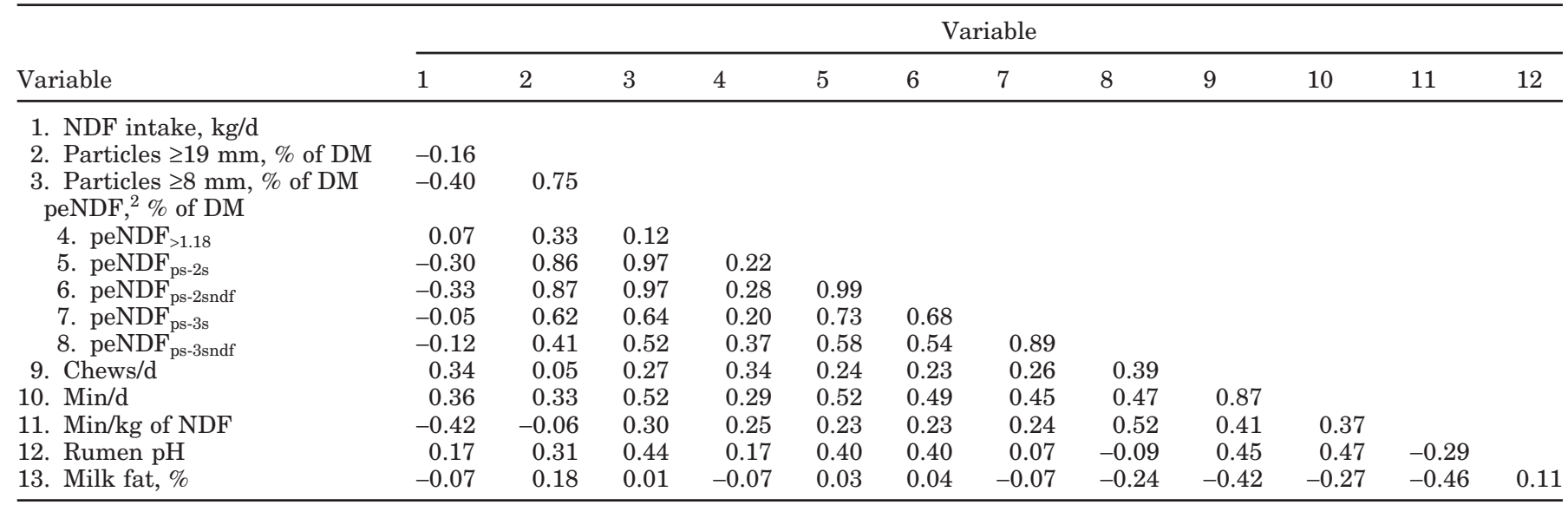

${ }^{1}$ Correlation coefficients were significant at $P<0.01$ ( $>0.59$ or $\left.<-0.59\right), P<0.05(>0.47$ or $<-0.47)$, and $P<0.10(>0.40$ or $<-0.40)$.

${ }^{2} \mathrm{peNDF}_{1.18}, \mathrm{peNDF}_{\mathrm{ps}-2 \mathrm{~s}}$, and peNDF $\mathrm{ps}_{\mathrm{ps}}=$ physically effective NDF determined as NDF content of diets multiplied by pef $\mathrm{f}_{1.18}$, pef $\mathrm{ps}_{\mathrm{ps}-2 \mathrm{~s}}$, and pef $_{\mathrm{ps}-3 \mathrm{~s}}$, respectively (Table 3); peNDF $\mathrm{ps}_{\mathrm{ps}-2 \mathrm{sndf}}$ and $\mathrm{peNDF}_{\mathrm{ps}-3 \mathrm{sndf}}=$ proportion of NDF retained on 2 sieves (Lammers et al., 1996) or on 3 sieves (Kononoff et al., 2003a), respectively.

and Heinrichs (2003a), who suggested that the proportion of particles $>19 \mathrm{~mm}$ may be a primary factor affecting chewing activity. It appears that the effect of the individual particle fractions of the PSPS on chewing activity depends on the relative contribution of each particle fraction to the pef (Beauchemin and Yang, 2005).

Ruminal $\mathrm{pH}$ was moderately correlated with particles $>8 \mathrm{~mm}(\mathrm{r}=0.44, P<0.10), \mathrm{peNDF}_{\mathrm{ps}-2 \mathrm{~s}}(\mathrm{r}=0.40, P<$ $0.10)$, peNDF $_{\mathrm{ps}-2 \mathrm{sndf}}(\mathrm{r}=0.40, P<0.10)$, number of chews $(\mathrm{r}=0.45, P<0.10)$, and chewing time $(\mathrm{r}=0.47$, Table 10$)$. Thus, mean ruminal $\mathrm{pH}$ was correlated with dietary peNDF measured using 2 sieves, despite the lack of statistically significant effects of treatment peNDF levels on ruminal $\mathrm{pH}$ (Table 9). This apparent contradiction can be explained by the fact that within treatment peNDF level (high, medium, and low), actual peNDF content of the diets consumed by individual cows was variable depending upon the degree of selectivity for and against long particles. The implication of these results is that even though a diet may be formulated to provide specific peNDF content, whether the diet promotes adequate chewing to maintain high rumen $\mathrm{pH}$ will depend on the individual cows. Thus, from a ration formulation approach, a margin of safety needs to be incorporated into recommendations for minimum peNDF.

Correlation of ruminal $\mathrm{pH}$ with dietary peNDF and with chewing activity coincides with the premise that increasing particle length increases chewing activity and salivary buffer production. However, this premise is not always consistent in studies, because the correlation between ruminal $\mathrm{pH}$ and chewing activity in the literature is usually poor (Krause et al., 2002b), espe- cially for diets containing highly fermentable ingredients such as barley grain (Beauchemin and Yang, 2005; Yang and Beauchemin, 2006). The relationship between peNDF and rumen $\mathrm{pH}$ is inconsistent because the concept of peNDF does not account for differences in ruminal fermentability of feeds, which can have a major impact on ruminal pH (Yang et al., 2001; Krause et al., 2002b). Furthermore, there is tremendous variability in ruminal $\mathrm{pH}$ among cattle, even when fed the same diet (Bevans et al., 2005).

\section{Choice of peNDF System}

The ability to differentiate the physical effectiveness of diets is essential in terms of predicting the biological response of the cow. In this study, dietary peNDF was positively associated with fiber digestibility, as well as chewing and ruminating time. However, there was no relationship between peNDF and milk production because the cows were in mid to late lactation. The contents of pef and peNDF of forage and TMR estimated using the new PSPS with 3 sieves or a 1.18-mm screen were similar, but higher than those obtained using the original PSPS with 2 sieves. However, determining peNDF using the systems that incorporate a $1.18-\mathrm{mm}$ sieve did not differentiate between diets differing in particle size distribution due to varying TCL of CS. Thus, $\mathrm{pNDF}_{\mathrm{ps}-3 \mathrm{~s}}$ and peNDF $\mathrm{N}_{1.18}$ did not appropriately determine dietary pef and peNDF of CS-based diets. Calculating the peNDF content of diets based on the fractional NDF content retained by the individual sieves, rather than the total NDF content of the sample, increased the values but did not change the classification of diets, particularly because the diets did not vary 
in proportion of concentrate. The disadvantage of a system with fractional NDF is that it requires more laboratory analyses (i.e., NDF determination), which greatly restricts its application, especially on farm. However, the fractional NDF system would be advantageous for differentiating peNDF of diets that vary in concentrate, particularly when the concentrates are of variable size, which would affect the proportions retained on the sieves.

The peNDF 1.18 was not correlated with chewing activity. In contrast, peNDF measured by both the original and new PSPS was positively correlated to chewing activity. Thus, the PSPS is a useful and practical device to determine the physical effectiveness of fiber, which is a good indication of the rumination potential of the feed. The consistency of chewing index, the ratio of total chewing activity to peNDF, across diets varying in chop length of CS when using the new PSPS would seem to indicate that it may be the best of the systems evaluated for measuring effects of diet on chewing time. However, the values for peNDF using the new PSPS were not different among diets that varied considerably in chop length of CS. This lack of variation makes this system difficult to use in ration formulation to account for effects of dietary differences in particle length. Thus, although each system evaluated in this study has its advantageous and disadvantages, it would appear that the PSPS with 2 sieves is the most useful of the systems evaluated for meeting the requirements of dairy cows for peNDF. The PSPS with 2 sieves differentiated diets based on particle size of forage and was correlated with chewing and ruminal $\mathrm{pH}$.

\section{CONCLUSIONS}

The study demonstrated the need to accurately quantify the physical effectiveness of diets in a manner that relates to the biological response of the cow. Increasing forage particle length increased intake of peNDF, which was positively associated with fiber digestion and chewing time. Of the various methods used to measure the physical effectiveness of fiber, the original PSPS with 2 sieves provided a better description of the variation in dietary physical effectiveness and the potential of the diet to promote chewing and prevent ruminal acidosis.

\section{ACKNOWLEDGMENTS}

This experiment was financially supported by the Dairy of Farmers of Canada (Ottawa, ON) and Agriculture and Agri-Food Canada's Matching Investment Initiative. The authors thank K. Andrews, B. Farr, A. Furtado, D. Vedres, R. Wuerfel, and Z. Xu for their assistance in performing sampling, ruminal $\mathrm{pH}$ and chewing measurements, and laboratory analyses, as well as the staff of the Lethbridge Research Centre dairy unit for care of the cows and milk sample collection.

\section{REFERENCES}

AOAC. 1990. Official Methods of Analysis. Vol. I. 15th ed. Association of Official Analytical Chemists, Arlington, VA.

Bal, M. A., R. D. Shaver, A. J. Jirovec, K. J. Shinners, and J. G. Coors. 2000. Crop processing and chop length of corn silage: Effects on intake, digestion, and milk production by dairy cows. J. Dairy Sci. 83:1264-1273.

Beauchemin, K. A., and L. M. Rode. 1997. Minimum versus optimum concentrations of fiber in dairy cow diets based on barley silage and concentrates of corn or barley. J. Dairy Sci. 80:1629-1639.

Beauchemin, K. A., and W. Z. Yang. 2005. Effects of physically effective fiber on intake, chewing activity, and ruminal acidosis for dairy cows fed diets based on corn silage. J. Dairy Sci. 88:2117-2129.

Beauchemin, K. A., W. Z. Yang, and L. M. Rode. 2003. Effects of particle size of alfalfa-based dairy cow diets on chewing activity, rumen fermentation, and milk production. J. Dairy Sci. $86: 630-643$

Bevans, D. W., K. A. Beauchemin, K. S. Schwartzkopf-Genswein, J. J. McKinnon, and T. A. McAllister. 2005. Effect of rapid or gradual grain adaptation on subacute acidosis and feed intake by feedlot cattle. J. Anim. Sci. 83:1116-1132.

Chen, X. B., and M. J. Gomes. 1992. Estimation of microbial protein supply to sheep and cattle based on urinary excretion of purine derivatives - An overview of the technical details. Int. Feed Res. Unit, Occ. Publ., Rowett Research Institute, Bucksburn, Aberdeen, UK.

De Boever, J. L., D. L. De Brabander, A. M. DeSmet, J. M. Vanacker, and C. V. Boucque. 1993. Evaluation of physical structure. 2. Maize silage. J. Dairy Sci. 76:1624-1634.

DeVries, T. J., M. A. G. von Keyserlingk, D. M. Weary, and K. A. Beauchemin. 2003. Measuring the feeding behavior of lactating dairy cows in early to peak lactation. J. Dairy Sci. 86:3354-3361.

Einarson, M. S., J. C. Plaizier, and K. M. Wittenberg. 2004. Effects of barley silage chop length on productivity and rumen conditions of lactating dairy cows fed a total mixed ration. J. Dairy Sci. 87:2987-2996.

Fernandez, I., C. Matin, M. Champion, and B. Michalet-Doreau. 2004. Effect of corn hybrid and chop length of whole-plant corn silage on digestion and intake by dairy cows. J. Dairy Sci. 87:1298-1309.

Fernandez, I., and B. Michalet-Doreau. 2002. Effect of maturity stage and chopping length of maize silages on particle size reduction in dairy cows. Anim. Res. 51:445-454.

Fischer, J. M., J. G. Buchanan, C. Campbell, D. G. Grieve, and O. B. Allen. 1994. Effects of forage particle size and long hay for cows fed total mixed rations based on alfalfa and corn. J. Dairy Sci. 77:217-229.

Kononoff, P. J., and A. J. Heinrichs. 2003a. The effect of reducing alfalfa haylage particle size on cows in early lactation. J. Dairy Sci. 86:1445-1457.

Kononoff, P. J., and A. J. Heinrichs. 2003b. The effect of corn silage particle size and cottonseed hulls on cows in early lactation. J. Dairy Sci. 86:2438-2451.

Kononoff, P. J., A. J. Heinrichs, and D. R. Buckmaster. 2003a. Modification of the Penn State forage and total mixed ration particle separator and the effects of moisture content on its measurements. J. Dairy Sci. 86:1858-1863.

Kononoff, P. J., A. J. Heinrichs, and H. A. Lehman. 2003b. The effect of corn silage particle size on eating behavior, chewing activities, and rumen fermentation in lactating dairy cows. J. Dairy Sci. 86:3343-3353.

Krause, K. M., and D. K. Combs. 2003. Effects of forage particle size, forage source, and grain fermentability on performance and ruminal pH in midlactation cows. J. Dairy Sci. 86:1382-1397.

Krause, K. M., D. K. Combs, and K. A. Beauchemin. 2002a. Effects of forage particle size and grain fermentability in midlactation 
cows. I. Milk production and diet digestibility. J. Dairy Sci. 85:1936-1946.

Krause, K. M., D. K. Combs, and K. A. Beauchemin. 2002b. Effects of forage particle size and grain fermentability in midlactation cows. II. Ruminal $\mathrm{pH}$ and chewing activity. J. Dairy Sci. 85:1947-1957.

Lammers, B. P., D. R. Buckmaster, and A. J. Heinrichs. 1996. A simple method for the analysis of particle sizes of forage and total mixed rations. J. Dairy Sci. 79:922-928.

Lindberg, J. E., and C. Jansson. 1989. A rapid automated analysis of allantoin in ruminant urine. Swed. J. Agric. Res. 19:163-168.

Mertens, D. R. 1997. Creating a system for meeting the fiber requirements of dairy cows. J. Dairy Sci. 80:1463-1481.

National Research Council. 2001. Nutrient Requirements of Dairy Cattle. 7th rev. ed. Natl. Acad. Sci., Washington, DC.

Onetti, S. G., R. D. Shaver, S. J. Bertics, and R. R. Grummer. 2003. Influence of corn silage particle length on the performance of lactating dairy cows fed supplemental tallow. J. Dairy Sci. 86:2949-2957.

Plaizier, J. C. 2004. Replacing chopped alfalfa hay with alfalfa silage in barley grain and alfalfa-based total mixed rations for lactating dairy cows. J. Dairy Sci. 87:2495-2505.

Penner, G. B., K. A. Beauchemin, and T. Mutsvangwa. 2006. An evaluation of the accuracy and precision of a stand-alone submersible continuous ruminal $\mathrm{pH}$ measurement system. J. Dairy Sci. 89:2132-2140.

Pentz, E. I. 1969. Adaptation of the Rimini-Schryver reaction for the measurement of allantoin in urine to the autoanalyzer: Allantoin and taurine excretion following meutron irradiation. Anal. Biochem. 27:333-342.

Poppi, D. P., and B. W. Norton. 1980. The validaty of the critical size theory for particles leaving the rumen. J. Agric. Sci. 94:275-280.

Rode, L. M., W. Z. Yang, and K. A. Beauchemin. 1999. Fibrolytic enzyme supplements for dairy cows in early lactation. J. Dairy Sci. 82:2121-2126.

SAS Institute. 1996. SAS User's Guide: Statistics. Version 7 ed. SAS Inst., Inc., Cary, NC.

Schwab, E. C., R. D. Shaver, K. J. Shinners, J. G. Lauer, and J. G. Coors. 2002. Processing and chop length effects in brown-midrib corn silage on intake, digestion, and milk production by dairy cows. J. Dairy Sci. 85:613-623.

Smith, K. A., and M. A. Tabatabai. 2004. Automated instruments for the determination of total carbon, hydrogen, nitrogen, sulfur, and oxygen. Pages 235-282 in Soil and Environmental Analysis Modern Instrumental Techniques. 3rd ed. K. A. Smith and M. S. Cresser, ed. Marcel Dekker, Inc., New York, NY.

Soita, H. W., D. A. Christensen, and J. J. McKinnon. 2000. Influence of particle size on the effectiveness of the fiber in barley silage. J. Dairy Sci. 83:2295-2300.

Soita, H. W., M. Fehr, D. A. Christensen, and T. Mutsvangwa. 2005. Effects of corn silage particle length and forage:concentrate ratio on milk fatty acid composition in dairy cows fed supplemental flaxseed. J. Dairy Sci. 88:2813-2819.

Van Soest, P. J., J. B. Robertson, and B. A. Lewis. 1991. Methods for dietary fiber, neutral detergent fiber and non-starch polysaccharide in relation to animal nutrition. J. Dairy Sci. 74:35833597.

Weatherburn, M. W. 1967. Phenol-hypochlorite reaction for determination of ammonia. Anal. Chem. 39:971-974.

Yang, W. Z., and K. A. Beauchemin. 2005. Effects of physically effective fiber on digestion and milk production by dairy cows fed diets based on corn silage. J. Dairy Sci. 88:1090-1098.

Yang, W. Z., and K. A. Beauchemin. 2006. Effects of physically effective fiber on chewing activity and ruminal $\mathrm{pH}$ of dairy cows fed diets based on barley silage. J. Dairy Sci. 89:217-228.

Yang, W. Z., K. A. Beauchemin, and L. M. Rode. 2001. Effects of grain processing, forage to concentrate ratio, and forage particle size on rumen $\mathrm{pH}$ and digestion by dairy cows. J. Dairy Sci. $84: 2203-2216$

Yansari, A. T., R. Valizadeh, A. Naserian, D. A. Christensen, P. Yu, and F. E. Shahroodi. 2004. Effects of alfalfa particle size and specific gravity on chewing activity, digestibility, and performance of Holstein dairy cows. J. Dairy Sci. 87:3912-3924.

Zebeli, Q., M. Tafaj, H. Steingass, B. Metzler, and W. Drochner. 2006. Effects of physically effective fiber on digestive processes and milk fat content in early lactating dairy cows fed total mixed rations. J. Dairy Sci. 89:651-668.

Zinn, R. A., and F. N. Owens. 1986. A rapid procedure for purine measurements and its use for estimating net ruminal protein synthesis. Can. J. Anim. Sci. 66:157-166. 